\title{
The emerging role of FTY720 (Fingolimod) in cancer treatment
}

\author{
Christopher White ${ }^{1, *}$, Heba Alshaker ${ }^{2,3, *}$, Colin Cooper $^{3}$, Matthias Winkler $^{4}$ and \\ Dmitri Pchejetski ${ }^{3}$ \\ 1 School of Medicine, Imperial College London, London, UK \\ 2 Department of Pharmacology and Biomedical Sciences, Faculty of Pharmacy and Medical Sciences, University of Petra, \\ Amman, Jordan \\ ${ }^{3}$ School of Medicine, University of East Anglia, Norwich, UK \\ ${ }^{4}$ Department of Surgery and Cancer, Imperial College London, London, UK \\ * These authors have contributed equally to this work \\ Correspondence to: Christopher White, email: christopher.white13@imperial.ac.uk \\ Heba Alshaker, email: ha.alsh@hotmail.com
}

Keywords: sphingolipid, sphingosine kinase, fingolimod, FTY720, cancer

Received: August 29, $2015 \quad$ Accepted: January 19, 2016

Published: February 02, 2016

\section{ABSTRACT}

FTY720 (Fingolimod) is a clinically approved immunomodulating therapy for multiple sclerosis that sequesters T-cells to lymph nodes through functional antagonism of sphingosine-1-phosphate 1 receptor. FTY720 also demonstrates a proven efficacy in multiple in vitro and in vivo cancer models, suggesting a potential therapeutic role in cancer patients. A potential anticancer mechanism of FTY720 is through the inhibition of sphingosine kinase 1, a proto-oncogene with in vitro and clinical cancer association. In addition, FTY720's anticancer properties may be attributable to actions on several other molecular targets. This study focuses on reviewing the emerging evidence regarding the anticancer properties and molecular targets of FTY720. While the clinical transition of FTY720 is currently limited by its immune suppression effects, studies aiming at FTY720 delivery and release together with identifying its key synergetic combinations and relevant patient subsets may lead to its rapid introduction into the clinic.

\section{TARGETING SPHINGOLIPID SIGNALLING FOR CANCER TREATMENT}

Introduction to sphingolipid metabolism

Sphingolipids are one of the major components of eukaryotic cell plasma membranes. Aside from their structural role, they have attracted attention as potent second messengers regulating programmed cell death. Cleavage of a pro-apoptotic sphingolipid ceramide yields pro-apoptotic sphingosine that is phosphorylated by sphingosine kinases (SKs) to anti-apoptotic sphingosine-1phosphate (S1P) (Figure 1). The dynamic balance between $\mathrm{S} 1 \mathrm{P}$ and sphingosine/ceramide signalling is referred to as the "sphingolipid rheostat" and determines whether a cell undergoes apoptosis (reviewed in [1-3]). S1P can be dephosphorylated or degraded [4] (Figure 1), and the balance of production and degradation of S1P is tightly regulated (reviewed in [5]). Importantly, the enzymes of the rheostat do not just function by directly changing the balance of metabolites, but also by the roles these metabolites have in a myriad of signaling pathways with production, localisation, secretion and signaling of these metabolites having profound effect on tumor outcomes [6].

Two SK genes expressed in humans, SK1 and SK2, display different catalytic properties [7] suggesting distinct physiological roles [8-10]. SKs possess an intrinsic catalytic activity [11] which is rapidly accelerated upon phosphorylation, [12] inducing its translocation to the plasma membrane [11]. SKs may have extracellular effects (reviewed in [13]). SK1 or SK2 single knockout in mice does not affect development and reproduction, whereas simultaneous knockout results in S1P deficiency and embryonic lethality [14]. SK1 is a proto-oncogene and is regulated through multiple mechanisms. Upon stimulation, SK1, located predominately in the cytosol, translocates to the plasma membrane and enhances S1P 
secretion and proliferative signalling [15] (Figure 2). Through binding cell surface S1P G-protein coupled receptors (S1PRs1-5), S1P initiates autocrine and paracrine signalling cascades that induce cell migration, angiogenesis and differentiation (reviewed in [16], (Figure 2 ). Diverse outcomes of S1P signalling depend on the cell type and the expression of $G$ proteins and S1PRs [17]. Acting as an intracellular second messenger S1P enhances proliferation and suppresses apoptosis (reviewed in [16]. Internalised upon ligand binding, S1PRs can then either resensitise or degrade [18] depending on ubiquitination status. S1P binding through mono-ubiquitination leads to resensitisation, whilst other agonists (e.g. FTY720) lead to degradation through poly-ubiquitination [19]. S1P has several non-receptor intracellular actions (reviewed in [20]) including binding histone deacetylases HDAC1 and HDAC2 and regulating gene expression epigenetically [21], and forming complexes with tumour necrosis factor (TNF) receptor-associated factor 2 (TRAF2) leading to increased nuclear factor kappa B (NF-kB) signalling [22].

In healthy cells, ceramide and sphingosine play a crucial role in physiological apoptotic machinery while S1P signalling leads to cell proliferation, migration, angiogenesis, inflammatory response and lymphocyte trafficking. In cancer cells, dysregulation of enzymes involved in sphingolipid metabolism to escape cell death leads to increased S1P signalling, often through aberrant expression of ceramide degrading enzymes, sphingosine kinases or S1PRs (reviewed in [23]). While this provides rationale for therapeutic targeting of these pathways, their important physiological role in other tissues (such as heart or liver) urges for extreme caution. In particular, targeting S1P may lead to lymphocyte retention in lymph nodes and subsequent lymphopenia, which would be an undesirable side effect, especially in cancer patients.

\section{Sphingosine kinase 1 as a potential therapy target for cancer treatment}

\section{Clinical and in vitro association}

Compelling evidence suggests that SK1 activation contributes to cancer progression. High SK1 expression has been shown in several human cancers including brain, breast, colon, lung, ovary, stomach, uterus, kidney, rectum and small intestine [24-27]. Expression of high levels of $\mathrm{S} 1 \mathrm{P}$ receptors, $\mathrm{S} 1 \mathrm{P} 1$ and $\mathrm{S} 1 \mathrm{P} 3, \mathrm{SK} 1$, and extracellular signal-regulated kinase-1/2 are associated with development of tamoxifen resistance in estrogen receptorpositive breast cancer patients [28]. This is the first study to demonstrate the association of survival rates and disease recurrence with combined S1P1/S1P3 and SK1 protein expression indicating a complex relationship between $\mathrm{S} 1 \mathrm{P}$ receptor and SK1 expression and outcomes. This may indicate the significance of the autocrine activation of this pathway in breast cancer cells and suggests that disruption of this pathway may provide a target for treatment of tamoxifen-resistant breast cancer [28].

High levels of SK1 expression/activity are associated with poor prognosis, decreased survival rate

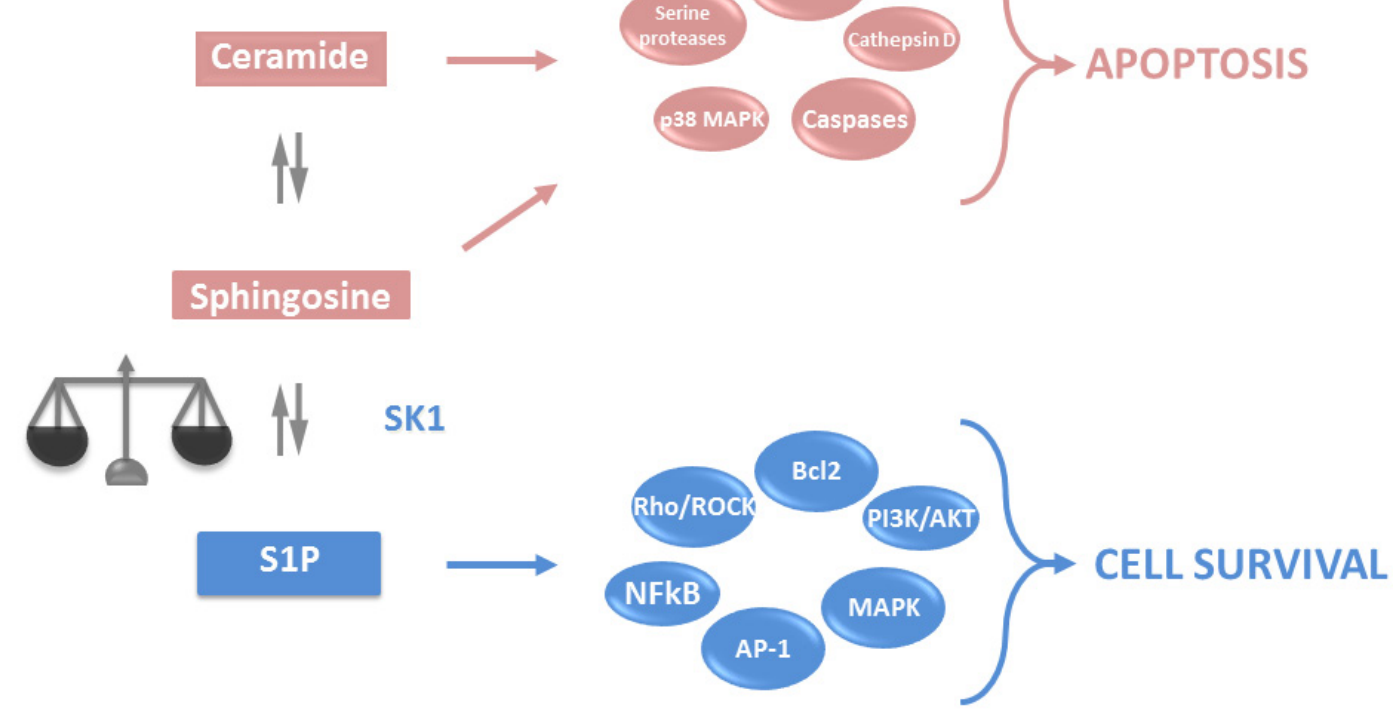

Figure 1: Sphingolipid rheostat. Ceramide and sphingosine are intracellular lipid second messengers, which induce activation of apoptotic pathways. In turn, SK1 can phosphorylate sphingosine to yield S1P, a lipid second messenger that activates anti-apoptotic pathways and antagonises the effects of ceramide and sphingosine. The intracellular balance between ceramide, sphingosine and S1P determines the cell fate. PKC - protein kinase C; MAPK - mitogen-activated protein kinases; JNK - c-Jun N-terminal kinases; SAPK - stress activated protein kinase; NFkB - nuclear factor kappa B; PLC - phospholipase C; Bcl2 - B cell lymphoma 2, AP-1 - activator protein 1 (reviewed in [248] and [249]). 
[25] and histologic grade [29] in glioma; poor prognosis in breast cancer patients [30]; prostate cancer progression (Prostate specific antigen (PSA), tumour volumes and Gleason score) and disease recurrence (positive margins and surgical failure) [31]; shorter survival time in gastric cancer patients [32]; poor survival and tumour progression in non-small cell lung cancer [33]; TNM status, tumour differentiation and shorter overall survival time in salivary gland cancer [34]; and advanced tumour stage, nodal involvement, recurrence, shorter patient survival time and loss of p21 expression in head and neck cancer [35, 36].

These associations have complex pathophysiological mechanisms. A hallmark study showed that enforced expression of SK1 is sufficient for malignant transformation of NIH-3T3 fibroblasts leading to serum independence and tumour formation [37]. The expression of SK1a and SK1b in androgen-independent LNCaP-AI prostate cancer cells is upregulated compared with androgen-sensitive LNCaP prostate cancer cells, suggesting that androgen escape might be associated with increased transcriptional up-regulation of SK1a/b [38]. Indeed, long-term androgen deprivation raises basal SK1 levels in prostate cancer cells, although the exact mechanism is not known [39]. This is confirmed in androgen-independent prostate cancer cells derived from patients' brain and bone metastases which have $\sim 10$-fold higher SK1 activity than androgen dependent prostate cancer cells derived from lymph nodes [40].

\section{Protection against apoptosis}

Many studies have shown that one of the major functions of SK1 is to provide cancer cells protection from apoptosis. Thus, targeting SK1 was quickly proposed as a potential therapeutic approach for cancer treatment. Indeed, many cancer cell lines are sensitive to treatment with either siRNAs to SK1 or pharmacological inhibitors of this enzyme [27, 40,41] independently of p53 mutation [40] or Bcl-2 status [42]. SK1 is upregulated in response to several anticancer treatments [40, 43, 44] leading to resistance of cancer cells to these therapies. Apoptosis-induced SK1 expression and subsequent release of S1P signals to tumour-associated macrophages and may therefore promote an inflammatory tumour microenvironment [45]. SK1 expression can protect the cells against apoptosis induced by TNF- $\alpha$ and Fas ligand $[46,47]$, and can mediate survival under stress conditions such as starvation $[37,48]$.
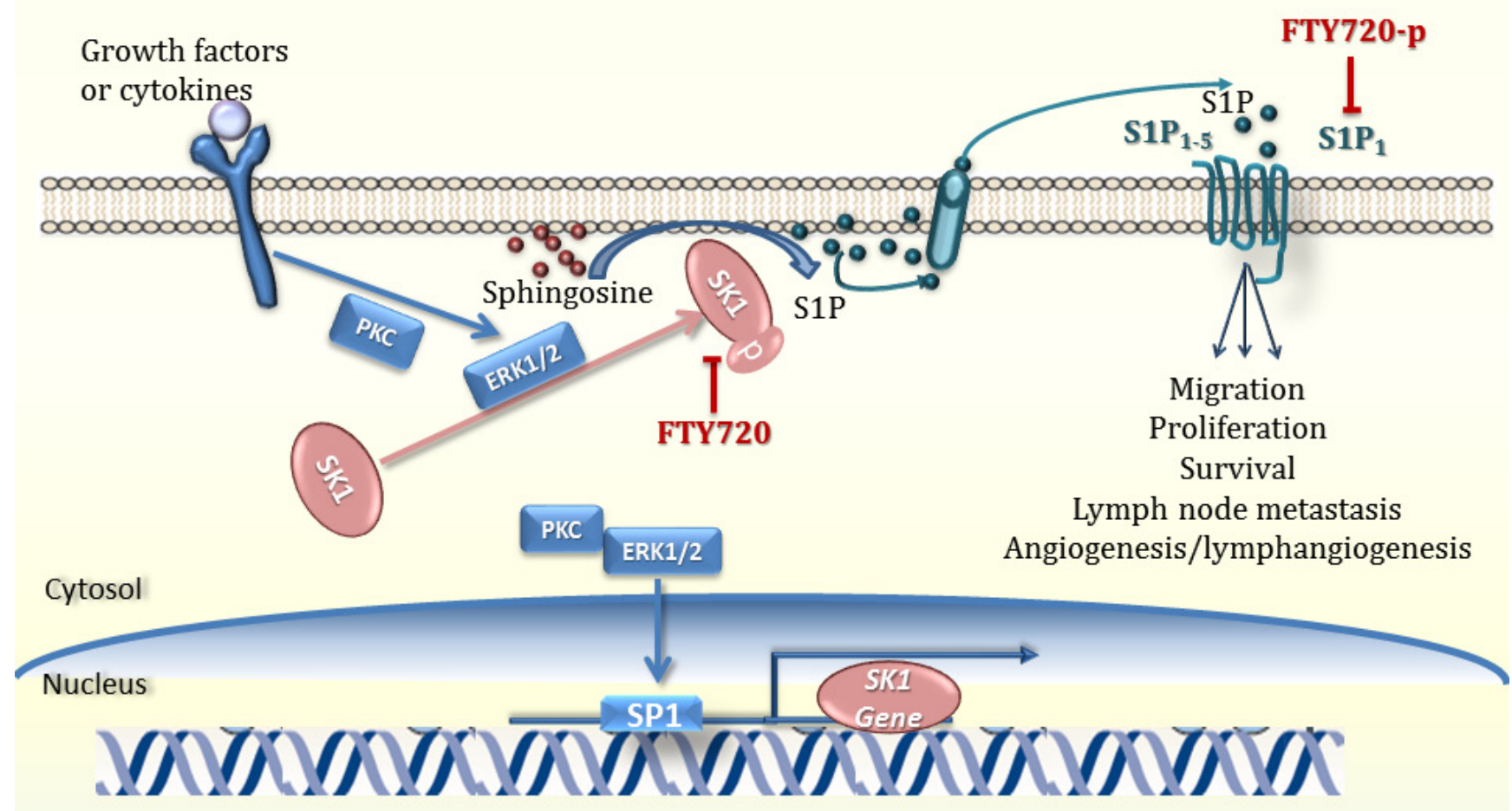

Figure 2. SK1/S1P signalling pathway. Tumour necrosis factor alfa, growth factors and cytokines activate receptor tyrosine kinases, G-protein coupled receptors, toll like receptors, which induce phosphorylation of sphingosine kinase 1 (SK1, often through ERK1/2 and $\mathrm{PKC}$ ), its translocation to plasma membrane and generation of sphingosine-1-phosphate (S1P) from sphingosine (reviewed in [250]). S1P can then be exported outside of the cell where it acts in a paracrine or autocrine manner and activates 5 specific S1P receptors (S1P1-5). Upon coupling with S1P, these receptors can activate downstream signalling pathways leading to cell proliferation, migration and gene expression. PKC - protein kinase C; (reviewed in [248] and [249]). 


\section{Inflammatory response}

In addition to blocking cancer cell death, it has been proposed that SK1 promotes pro-inflammatory cytokine release [49]. Extracellular S1P induced COX2 overexpression and PGE2 production in L929 fibrosarcoma and A549 lung adenocarcinoma cells [50]. S1P secreted from apoptotic tumour cells could induce macrophage polarisation [51] and stimulated chemotaxis of primary monocytes and macrophages, whereas S1P antibody abrogated macrophage invasion to ischemic areas [52]. Tumour associated macrophages (TAMs) are strongly associated with a poor prognostic outcome in cancer patients and induce $\mathrm{TNF} \alpha$-dependent activation of JNK and NF- $\kappa \mathrm{B}$ in adjacent tumour cells to promote their growth, motility and invasion [53, 54]. TAMs secrete promigratory cytokines/chemokines, including those released in response to activation of the SK1/S1P pathway $[50,55]$. The SK1/S1P pathway is involved in inflammatory responses to cytokines such as TNF $\alpha$ and interleukin (IL-1) [56]. TNF $\alpha$, via a TRAF2-dependent mechanism, activates SK1 leading to activation of the pro-survival and pro-inflammatory pathways mediated by AKT $[57,58]$ and NF- $\kappa \mathrm{B}[58]$ through ubiquitination of receptor interacting protein 1 and stimulation of $\mathrm{I \kappa B}$ kinase [22]. However, in both murine macrophages lacking both $S K 1$ and $S K 2$ and WT macrophages, TNF $\alpha$ and LPS induced similar inflammatory responses and activated the NFאB pathway to a similar extent, possibly suggesting that intracellular S1P is not necessary for the activation of this critical inflammatory signaling pathway [59].

\section{Migration}

Activation of SK1 downstream of several chemotactic receptors (e.g. lysophosphatidic acid (LPA1). epidermal growth factor or platelet-derived growth factor) $[60,61]$ enhances metastatic potential of cancer cells $[62$, 63 ] and cancer cell migration [64-68]. In many instances SK1-induced cell migration is mediated by S1P secretion and coupling to S1P receptors [69]. S1P1, S1P3 and S1P4 receptors mediate promigratory responses [70-72][50] through activation of Rac signalling, actin polymerization and lamellipodia formation. S1P2 (except in fibroblasts [73]) and S1P5 mediate cessation of migration through stimulation of Rho and Rac leading to stress fiber formation [74-76], suggesting the effect of S1P depends on differential expression of S1PRs in a specific cell type. In U373 glioblastoma cells SK1/S1P-induced cancer cell migration was linked with expression of plasminogen activator inhibitor-1 (PAI-1) and urokinase receptor (UPAR) [77]. Induction of cancer cell migration may also occur through intracellular non-receptor mechanisms, for example in hepatocyte growth factor-induced migration of endothelial cells [78]. The formation of a signalling complex between SK1, S1P1 and the cytoskeletal protein filamin A that localises to membrane ruffes of migrating cells to promote cell movement has been reported [66].

\section{Neovascularisation}

SK1/S1P signalling enhances tumour neovascularisation [79]. S1P secreted from tumour tissue can act as a chemoattractant for various cells including vascular endothelial cells [79]. S1P promotes endothelialcell growth and interacts with vascular endothelial growth factor VEGF signalling [80]. VEGF stimulated S1P production mediated activation of RAS and MAPKs in T24 bladder tumour cells [81]. S1P1 expression is strongly induced in tumour vessels and specific knockdown of S1P1 significantly abrogates angiogenesis in murine models [82]. Secreted S1P initiated endothelial cell sprouting in 3-dimensional collagen matrices [83]. Antibodies to S1P have antitumour potential [63] through inhibition of cell proliferation, release of proangiogenic cytokines (e.g. VEGF, IL-8 and IL-6) and blocking S1Prelated angiogenesis [63].

\section{Chemoresistance}

SK1 plays a role in chemoresistance and SK1 inhibition is proposed to correlate with chemotherapy efficiency [40]. SK1 overexpression inhibits chemotherapy-induced apoptosis: anthracyclines in MCF7 breast cancer cells [47]; doxorubicin and etoposide in HL-60 acute myeloid cells [41]; camptothecin and docetaxel in PC3 and $\mathrm{LNCaP}$ prostate cancer cells [40]; and MDR-associated chemoresistance in an acute myeloid leukemia (AML) model [41]. In prostate cancer cell lines and animal models indirect SK1 inhibition was a valid chemotherapeutic strategy [84]. Modulation of SK or S1P lyase has been suggested to contribute to altered sensitivity to cisplatin [85]. In vitro and in vivo models of prostate cancer demonstrated that the SK1/ S1P pathway has the potential to synergise with the effects of camptothecin chemotherapy [86], docetaxel chemotherapy [87] and radiotherapy [88]. SK1 inhibition restored endocrine response in breast cancer cells [89], and decreased colony formation [90], cell motility and chemotaxis $[49,91]$. Pharmacological inhibition of SK1 results in resensitisation to anticancer therapies [41, 92, 93], notably through targeting SK1 to the ubiquitinproteasomal degradation pathway and lowering SK1a/b levels below a threshold required for survival [38].

\section{Therapeutic potential of sphingosine kinase 1 inhibition}

SK1 is a potential target in cancer therapy. Dimethylsphingosine (DMS), a non-selective SK inhibitor [94] and its methylated derivative N,Ndimethylsphingosine (DMS) induce apoptosis in numerous cancer cells [94, 95], reviewed in [96]), inhibit in vivo growth of lung and gastric carcinoma tumours in athymic mice [97], decrease lung metastasis of melanoma cells in 
syngeneic mice [98], and induce apoptosis and sensitise LNCaP cells to gamma-irradiation-induced apoptosis [99]. Lacking specificity, DMS inhibits protein kinase C, phospholipase A2, and phospholipase D [100].

F-12509A and B-5354c are SK inhibitors with greater specificity [101]. F-12509A induces cancer cell apoptosis in imatinib-resistant cells [102], and in HL-60, HL-60/Doxo and HL-60/VP16 cells leading to nuclear fragmentation, caspase-3 cleavage, downregulation of XIAP, cytochrome $\mathrm{C}$ and SMAC/Diablo release [41]. B-5354c induces apoptosis in $\mathrm{LNCaP}$ and $\mathrm{PC}-3$ prostate cancers which is reversed by upregulation of SK1 [86].

2-(p-hydroxyanilo)-4-(p-chlorophenyl)thiazole (SKI-II), a SK-selective inhibitor has anti-cancer effects. SKI-II is cytotoxic to T24 bladder carcinoma cells, and MCF-7 and MCF-7/VP breast cancer cells [27]. SKI-II induces apoptosis in $\mathrm{LNCaP}$ and $\mathrm{PC}-3$ human prostate cancer cells, irrespective of their p53 status [40]. Upon intraperitoneal administration of SKI-II, tumour size decreases and tumour growth is inhibited by $50-80 \%$ [103]. SKI-II abrogates androgen receptor signalling via an oxidative stress-induced, p53-independent mechanism in prostate cancer cells [104].

Selective SK1 inhibitor (SK1-I) ([(2-hydroxy-1naphthyl)methylene]-3-(2-napythyl)-1H-pyrazole-5carbohydrazide) induces apoptosis of leukaemia cells but not normal bone marrow derived cells [105].

Further SK1-specific inhibitors have been developed through modifications of sphingosine [106], and amidinebased subtype-selective SK1 inhibitors. These inhibitors induce reduction of endogenous S1P levels in human leukemia cells at nanomolar concentrations [107]. (S)FTY720 vinylphosphonate [108] and sphingo-guanidines (LCL146 and LCL351) [109] induce SK1 inhibition in breast and prostate cancer cells and decrease migration rate of human prostate DU145 cells. New SK inhibitors optimised for selectivity and activity include SK1-178, which is active in vitro and in vivo and may help discern the role the SK1 and SK2 in disease development and progression [110].
L-threo-dihydrosphingosine (safingol) has sphingosine kinase-inhibiting properties [111]. A Phase I clinical trial of safingol, in combination with cisplatin in 43 cancer patients, reported safe use, reduction in S1P in plasma, significant regression of liver and lung metastases in one adrenal cortical cancer patient, and prolonged stable disease in another patient [112].

More recently, SK1 inhibitors with sub-micromolar potency have been more thoroughly characterized. In several studies, these more selective SK1 inhibitors did not demonstrate cytotoxic effects. For example, PF-543, with a K(i) of 3.6nM and an IC50 of 2nM for SK1, had no effect on proliferation and survival of various cancer cell lines including head and neck carcinoma cells [113]. Through use of sub-micromolar amidine-based SK1 inhibitors, a lack of correlation between SK1 inhibition with changes in cell survival in U937, Jurkat T and SKOV3 cells was demonstrated [114]. Potent and specific SK1/2 inhibitors completely inhibited intracellular S1P production in human cells and attenuated vascular permeability in mice, but did not lead to reduced tumor cell growth in vitro or in vivo [115]. While the cytotoxic effects demonstrated by older less specific SK1 inhibitors may be explained by their off-target effects rather than by their action on SK1, there is significant evidence showing anticancer cytotoxic effects of SK1 siRNAs [116-119]. Conversely, one recent paper showed that siRNA targeting SK1 in a large panel of cell lines failed to demonstrate any statistically significant effects on cell viability [115].

\section{FTY720 AS A NEW MOLECULAR THERAPY FOR CANCER TREATMENT}

\section{FTY720}

FTY720 (Fingolimod, Gilenya) (Figure 3) is a structural analogue of sphingosine developed from the fungal metabolite myriocin [120]. A phenylene moiety in

A.

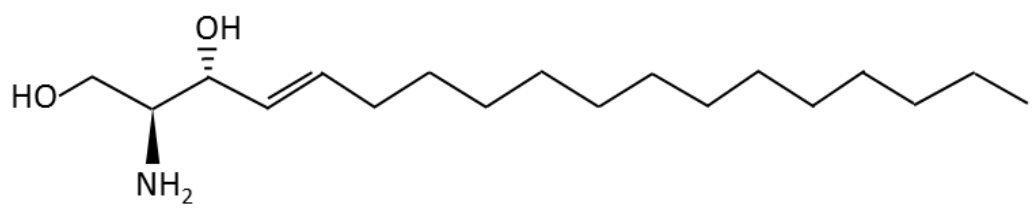

B.

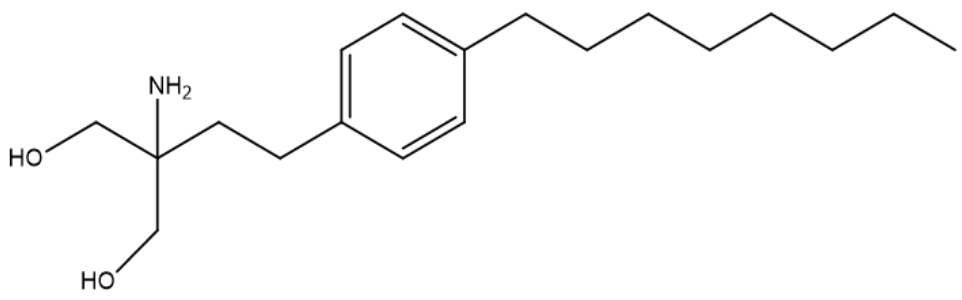

Figure 3: Structures of sphingosine (A) and FTY720 (B). 
FTY720's side chain confers potent immunosuppressive activity [121]. FTY720 is phosphorylated by SK2 to form FTY720-phosphate (FTY720-p), but is not phosphorylated, or phosphorylated with low efficiency, by SK1 [88, 108, 122-128]. FTY720-p is an agonist of S1Prs 1, 3, 4 and 5 and same time a functional antagonist of S1PR1 receptor [124, 129]. Through internalization and degradation of lymphocytes' S1PR1 receptor, FTY720 inhibits lymphocytes' egress from secondary lymphoid tissues and thymus and induces lymphopaenia [71, 130134]. In multiple sclerosis FTY720 acts upon naïve and central memory T-cells without affecting peripheral effector memory cells [135]. The U.S. Food and Drug Administration (FDA) have approved FTY720 as a firstline treatment in relapsing forms of multiple sclerosis [136]. Owing to its cardio-protective effects FTY720 is a candidate for heart failure and arrhythmia treatment [137-140]. FTY720 has failed phase III clinical trials as an immunosuppressant for use in kidney transplantation $[141,142]$.

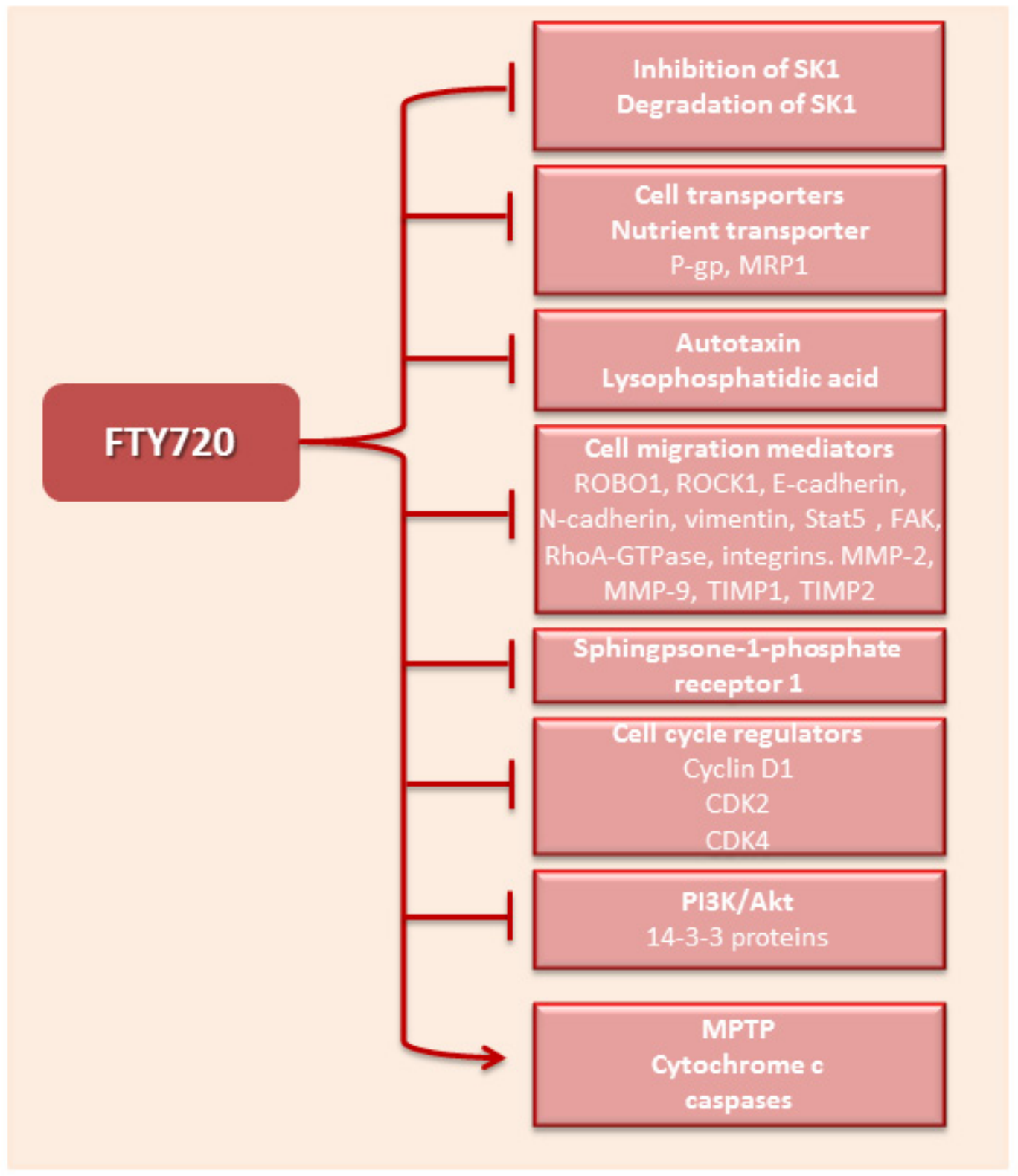

Figure 4: Molecular targets of FTY720. FTY720 inhibits SK1 and blocks the activation of multiple targets of this enzyme. In addition it can directly or indirectly inhibit multiple intracellular targets responsible for cell proliferation, migration and angiogenesis. It further activates mitochondrial permeability transition pore (MPTP), cytochrome c and effector caspases. P-gp - P-glycoprotein, MRP1 - multidrug resistance protein, ROBO1 - roundabout homolog 1, ROCK1 - rho-associated, coiled-coil-containing protein kinase 1, Stat5 signal transducer and activator of transcription 5, FAK - focal adhesion kinase, MMP - matrix metalloprotease, TIMP - tissue inhibitor of metallopeptidase, CDK - cyclin-dependent kinase. 


\section{Anti-cancer properties of FTY720}

FTY720 demonstrates anti-cancer properties and may have potential in cancer treatment. In vitro and in vivo studies demonstrate the growth arrest and apoptosisinducing ability of FTY720 in diverse normal and cancer cells including: lymphocytes [143, 144], microglia [145], prostate cancer [88, 108, 146-149], breast cancer [108, $122,150,151]$, several forms of leukaemia and lymphoma [152-159], lung cancer [160-162], liver cancer [163-166], pancreatic cancer [167, 168], bladder cancer [169], renal cancer [170, 171]; glioma [172], gastric cancer [173], colon cancer [151, 174] and ovarian cancer [175].

FTY720 is also a therapy sensitiser. Treatment of colorectal cancer cells with FTY720 shows an additive effect with 5-fluorouracil, SN-38, and oxaliplatin [176], and results in resensitization to cetuximab both in vitro and in vivo with inhibition of tumour growth, interference with signal transduction, induction of cancer cells apoptosis and prolongation of mice survival [177]. FTY720 significantly augments treatment efficacy and overall survival of mice receiving allogeneic adoptive cell transfer [178].

FTY720 inhibits metastasis in a mouse model of melanoma [179] and glioblastoma cell lines [180], and is able to inhibit microvessel formation and reduce expression of the angiogenesis promoting factor VEGF in androgen independent prostate tumour xenograft in nude mice [146]. FTY720 has strong immunosuppressive properties against TREG cells [181] that contribute to tolerance of malignant tumour cells [182] indicating FTY720 may have potential in post transplant malignancies [183].

\section{FTY720 inhibits sphingosine kinase 1}

One of the most studied anticancer mechanisms of FTY720 is inhibition or degradation of SK1 (Figure 4). SK1 downregulation is not dependent on FTY720 phosphorylation; in SK2 ${ }^{-/}$mice FTY720 decreased SK1 and S1PR1 expression, and eliminated the NFאB/ IL-6/STAT3 amplification cascade and development of colitis-associated cancer [184, 185]. FTY720 may inhibit SK1 through multiple mechanisms. In cell lines FTY720 has been shown to inhibit SK1 intracellular activity $[88,108,122,123]$ and it was shown that the in vitro IC50 of FTY720 for SK1 is 50uM [108]. FTY720 was demonstrated to be a competitive SK1 inhibitor with respect to sphingosine with an in situ Kic of 2 $\mathrm{mmol} / \mathrm{L}$ [108, 122]. Inhibitor characterization studies reveal that (S)-FTY720 vinylphosphonate inhibits SK1 in an uncompetitive manner, whereas a conjugate of sphingosine with a fluorophore and (S)-FTY720 regioisomer stimulate SK1 activity indicating the presence of allosteric site(s) [122]. Moreover FTY720 and (S)FTY720 vinylphosphonate, in addition to other direct
SK1 inhibitors [186, 187], induce SK1 degradation via ubiquitination and proteasomal processing [108]. This effect could be mediated by accumulation of ceramide and subsequent ceramide-induced activation of the proteasome [131]. In cisplatin-resistant SK-Mel-28 melanoma cells FTY720 induces SK1 degradation by p53-independent caspase activation and may inhibit the PI3K/Akt/mTOR pathway, related to chemoresistance mainly through escape from apoptosis [188]. Conversely in prostate cancer cell lines and mouse tumors FTY720-mediated radiosensitization is facilitated by SK1 inhibition and is caspase independent, suggesting a mechanism involving depletion of prosurvival signaling (e.g., Akt, SK1/S1P) [88]. In vitro, SK1 inhibition by FTY720 was shown to lead to prostate cancer cells apoptosis [88] and reduction of the expression of the androgen receptor [134].

\section{FTY720 reactivates protein phosphatase $2 \mathrm{~A}$}

Further to its effects on SK1, the nonphosphorylated form of FTY720 has been shown to mediate protein phosphatase $2 \mathrm{~A}(\mathrm{PP} 2 \mathrm{~A})$ reactivation $[155$, 156]. PP2A is a tumour-suppressor that is down-regulated in many cancers $[155,156,176,189-193]$ resulting in PI3K/Akt/mTOR activation (reviewed in [194]). The FTY720 mediated PP2A reactivation appears important in its apoptosis-inducing effects in many cancers [153, 155, 156, 190, 195, 196]. FTY720 enhanced purified PP2A activity [153] suggesting a direct effect [196], and also induced its reactivation in vitro by down-regulation of SET, a PP2A inhibitory protein often upregulated in cancer $[155,156,176]$. Ceramide, structurally similar to FTY720, activates PP2A [197-200], via direct disruption of SET [201]. Sphingosine activates PP2A via disruption of acidic leucine-rich nuclear phosphoprotein-32A (ANP32A) [202]. FTY720 mediated PP2A reactivation induces caspase-dependent apoptosis, affects Akt and extracellular signal-regulated kinase (ERK)-1/2 activation status, and impairs proliferation and clonogenic potential in colorectal cancer cells [176]. In lung cancer cells FTY720 mediated inhibition of SET-driven epithelialto-mesenchymal transition (EMT), through a SET/ PP2A/c-myc/NDRG1/Snail pathway, restored sensitivity to cisplatin, and inhibited invasiveness and growth of lung tumor xenografts [203]. PP2A is deregulated in $59.6 \%$ of basal breast tumours and oestrogen receptor negative breast cancer cell lines are sensitive to lower doses of FTY720 [193]. FTY720 mediated activation of the core PP2A complex dephosphorylates the mTOR downstream effectors, 4EBP and S6K, and concurrently releases the block on the p53 pathway [193]. Expression of the PP2A regulatory B subunit B55 $\alpha$ (PPP2R2A) is reduced in acute myeloid leukemia cells and suppression of B55 $\alpha$ in OCI-AML3 cells induces resistance to FTY-720 [204]. Reactivation of PP2A by FTY720 or its nonimmunosuppressive derivatives (S)-FTY720- 
OMe, (S)-FTY720-regioisomer and OSU-2S suppressed survival of chronic myeloid leukemia, but not quiescent haematopoietic stem cells in vitro and in vivo [205]. OSU-2S induces activation of PP2A, phosphorylation at the putative PKC substrate motif, nuclear translocation of SHP1S591 (PTPN6) and deregulation of multiple cellular processes in chronic lymphocytic leukemia (CLL) culminating in potent cytotoxicity [206]. FTY720 disrupted the SET-PP2A interaction, which inhibited BCRABL1-recruited JAK2 and impaired $\beta$-catenin-dependent survival through GSK-3 $\beta$ activation [205]. In Jak2V617F cells, FTY720 anti-leukaemic activity does not require FTY720 phosphorylation, SET dimerization nor ceramide induction, but depends on interaction with SET K209. Jak2V617F utilizes an alternative SK1-mediated pathway to inhibit PP2A, and FTY720-P acting as a S1P1 agonist elicits signals leading to the Jak2-PI-3K $\gamma$-PKC-SETmediated PP2A inhibition [207]. Targeting of I2PP2A/ SET by FTY720 suppresses lung tumour growth at least in part via PP2A activation and necroptosis mediated by the kinase domain of RIPK1 [208].

\section{Other targets of FTY720}

\section{S1PRs}

The anti-cancer properties of FTY720 are largely independent of its phosphorylation and effects upon S1P receptors. AAL(S), a close structural analogue of FTY720 that cannot be phosphorylated by SK2, lacks immunosuppressive effects, but induces apoptosis in lymphocytes [209]. Of note, FTY720 induces a downregulation of S1P1 in hepatocellular carcinoma [210]. In Hodgkin lymphoma cells S1P-induced migration was inhibited by an S1PR1 antagonist and FTY720-p, but potentiated by an S1PR2-specific antagonist [211]. In contrast, FTY720-P has been demonstrated to induce growth of breast and colon cancer cells [151].

\section{Autotaxin}

Autotaxin, an enzyme that produces lysophosphatidic acid from lysophosphatidylcholine in plasma, is associated with increased cancer invasion, metastasis and angiogenesis, and is over-expressed in several human cancers [212-218]. FTY720-p competitively inhibits autotaxin while FTY720 does not [219]. Conversely, FTY720 reduces plasma lysophosphatidic acid in mice [219].

\section{Apoptotic pathways}

FTY720 induces mitochondrial permeability transition and cytochrome c release via an influence on the permeability transition pore complex and $\mathrm{F}_{0} \mathrm{~F}_{1}$ ATPase [159]. Cytochrome c binds to Apaf-1 and activates caspases that induce apoptotic cell death, which is inhibited by Bcl-2 overexpression [159]. Activation of caspases has been implicated in FTY720's pro-apoptotic action [147, 148, 163, 179]. In multiple myeloma cells and rat thymocytes FTY720 induces activation of caspase-8, -9 , and -3 ; poly(ADP-ribose) polymerase cleavage; induces mitochondrial membrane potential and Bax cleavage and translocation of cytochrome c and SMAC/ Diablo from mitochondria to the cytosol [157, 220]. FTY720 induces apoptosis of leukemic cells via activation of BIM and BID, which promiscuously bind and inhibit anti-apoptotic Bcl-2 proteins Bcl-2, Bcl- XL and MCL1, and also activate BAX and BAK [221]. Bcl-2 levels regulate the sensitivity to FTY720 in T cell selective apoptosis [222]. A Fas-independent, Bcl-associated signal transduction pathway and inhibition of ERK activity may be involved in FTY720's anti-cancer properties [223]. The anticancer effect of FTY720 on androgen independent prostate tumour xenografts is mediated through regulating the expression of cell cycle inhibitors such as p21Waf1 and promoting apoptosis through modification of apoptosis regulators such as Bcl-2 and caspases [146].

\section{PI3K/Akt}

In a liver tumour rat model FTY720 suppresses tumour growth and progression by selective induction of apoptosis of tumour cells via down-regulation of phospho-Akt (ser473) and up-regulation of cleaved caspase-3, together with decrease of focal adhesion kinase [163]. In human prostate cancer cell lines and mouse tumors FTY720-mediated radiosensitization is caspase independent and linked to SK1 inhibition and downregulation of p-Akt [88]. In human breast cancer cells FTY720 potentiates radiation effects through perturbation of PI3K/Akt and p42/44 mitogen-activated protein kinase MAPK [224]. FTY720 down-regulates IL6-induced phosphorylation of Akt, signal transducers and activators of transcription 3 (Stat3), and MAPK; insulinlike growth factor-I-triggered Akt phosphorylation; and

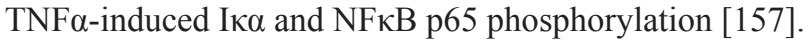
In neuroblastoma cells FTY720-induced cell death, alone or in combination with topotecan, is caspase-independent and induces dephosphorylation of Akt and its downstream effector BAD with release of cytochrome c, which the authors suggested to be due to involvement of 14-3-3 proteins [225]. Indeed, FTY720 and sphingosine bind directly to and regulate the function of pro-survival ubiquitous phospho-serine binding 14-3-3 proteins. Expression of non-phosphorylatable 14-3-3 in cells attenuates apoptosis upon FTY720 treatment [226] and protein kinase A [227] and PKCsigma [228] phosphorylate 14-3-3 in a sphingosine-dependent manner. Recently it was suggested that FTY720 induced inhibition of PI3K/ Akt pathway is mediated by phosphorylation of PP2A [229].

FTY720-induced inhibition of PI3K/Akt pathway downregulated mTOR signalling, which was shown to be crucial for FTY720-mediated inhibition of migration 
and invasion of glioblastoma cells [230]. mTOR is a key player in prosurvival cell signalling most notably regulating transcription and activity of multiple signalling molecules through its downstream targets S6 kinase and EIF4E transcription factor. It was demonstrated that FTY720-induced chemo-sensitization of cisplatin resistant melanoma cells is mediated by reduction of mTOR activity and the decrease in epidermal growth factor receptor expression [188].

\section{Cell cycle}

FTY720 treatment results in time-dependent downregulation of cyclin D1 and accumulation of cells in $G(0)-G(1)$ and $G(2)-M$ phases of the cell cycle with concomitant decrease in S-phase entry [154]. In prostate cancer cells FTY720 acts through modulation of mitogenic signaling, cell-cycle regulators (e.g. a decrease in CDK2 and CDK4 and induction of Cip1/p21) and induction of $\mathrm{G}_{1}$ arrest, and apoptotic death mediated by mitochondrial death pathway as well as the contribution of FAK to MAPK pathways [147].

\section{Cell transporters}

Some report propose that FTY720's anti-cancer activity may be due to its ability to induce nutrient transporter down-regulation [231] or inhibition of P-glycoprotein (P-gp) and multidrug resistance protein [174].

\section{Autophagy}

The evidence about the role of FTY720 in autophagy is controversial. FTY720 can induce U266 multiple myeloma cell apoptosis and autophagy with reactive oxygen species (ROS) regulating both of these processes [232]. However, this is not always beneficial, since in a variety of ovarian cancer cell lines including cisplatin-sensitive and cisplatin-resistant cells, the autophagy induction by FTY720 was antagonistic to cisplatin-mediated apoptosis [233]. A recent study shows that a combination of FTY720 and $\gamma$-irradiation blocks the autophagy flux causing a paradoxical increase of autophagosomes in breast cancer cells that die through apoptosis [224]. Finally, it was reported that FTY720 was effective in limiting murine metastatic melanoma development in vivo and induced apoptosis regulated by ROS and by increased expression of $\beta$-catenin in vitro without indications of autophagy or necroptosis [234].

\section{Cell migration}

FTY720 may reduce cell invasion and migration through several mechanisms. FTY720 modulates roundabout homolog 1 (ROBO1), rho-associated, coiledcoil-containing protein kinase 1 (ROCK1) and epithelial to mesemchymal (EMT) related factors such as E-cadherin, $\mathrm{N}$-cadherin and vimentin [235]. FTY720 down regulates matrix metalloprotease (MMP)-2 \& MMP-9 and upregulates tissue inhibitors of metalloproteinases: TIMP1
\& TIMP2 [236]. Finally, FTY720-mediated reduction ion cell migration was reported to be mediated by its effects on Bcl-2 [146, 154, 167, 170], Stat5 [156], PI3K/Akt/ mTOR/p70S6K pathway [147, 154, 236, 237], FAK [147], RhoA-GTPase [149] and integrins [167].

\section{EXPERT COMMENTARY}

The fact that FTY720 is an FDA-approved drug for treatment of progressive multiple sclerosis [238, 239] can significantly simplify its clinical implementation for other uses, in the case that a clinical benefit is demonstrated. However, despite its promising actions against a diversity of cancers, FTY720's S1PR-mediated immunosuppressive effects involving T-cell sequestration to lymph nodes limit its potential in cancer treatment. T-cells are considered as one of the most important mechanisms of anti-cancer defence and phosphorylated FTY720 inhibited random migration, cytotoxicity and tumour infiltration of activated CD3(+)NKG2D(+)CD8(+) T-lymphocytes in a mouse xenograft model [240]. In addition to its direct antitumour effect, FTY720 has strong immunosuppressive properties, specifically against regulatory $\mathrm{T}$ cells [181], which can contribute to tolerance of malignant tumour cells [182]. It has therefore been suggested to evaluate the use of FTY720 in patients with post-transplant malignancies [183]. There are several reports suggesting a direct influence of FTY720-p on cancer cells ranging from induction of growth in breast and colon cancer cells to inhibition of cancer cell migration. Currently, there is no consensus about the overall role of FTY720-p in cancer progression.

These potentially undesired effects of FTY720-p can be overcome by several ways. One potential way is by blocking FTY720 phosphorylation. OSU-2S, a synthetic derivative of FTY720, demonstrates more potent anti-tumour activity and lacks S1PR-mediated immunosuppressive effects [241]. OSU-2S displays satisfactory pharmacokinetic properties as shown using a liquid chromatography-tandem mass spectrometry (LCMS/MS) [242]. Through CCL tumour antigen ROR1targeted delivery, OSU-2S induces activation of PP2A, phosphorylation and nuclear translocation of SHP1S591 and deregulation of multiple cellular processes in $\mathrm{CCL}$ resulting in potent cytotoxicity [206].

Another way of limiting the immune suppressing effects of FTY720 is its tissue targeting and release control. A liposomal carrier of FTY720 (LP-FTY720) exhibits high drug loading ratio, prolonged in vitro release rate and beneficial pharmacokinetic properties in vivo compared to free FTY720 [243]. Incorporating tumour specific antibodies (anti-CD19, anti-CD20 and anti-CD37) achieved higher delivery and killing efficiency in primary CLL cells ex vivo which may be beneficial for targeting hematologic diseases where FTY720 induces $\mathrm{T}$ cell apoptosis [243]. Enhanced 
targeting of FTY720 through CD37 and CD19 dual immunoliposomes may improve the clinical efficacy of FTY720 in B-Cell lymphocytic leukaemia [244].

Alternatively, the immunosuppressive action of FTY720 can be reduced by a blockade of immune inhibitory pathways using anti-CTLA- $4 \mathrm{mAb}$, anti-PD-L1 $\mathrm{mAb}$, and/or the indoleamine-pyrrole 2,3-dioxygenase (IDO) inhibitor INCB23843 which restored IL-2 production, proliferation of intratumoural $\mathrm{T}$ cells, and tumour growth control in FTY720 treated murine B16. SIY melanoma model [245].

Another way of exploiting FTY720's anti-cancer activity is to mimic its effects on downstream targets using alternative small molecule inhibitors. An example of such approach is FTY720-induced nutrient transporter down-regulation [231]. O-substituted benzyl ethers of pyrrolidines induce nutrient transporter down-regulation and lack FTY720's S1P receptor-related dose-limiting toxicity in human leukaemia cells [231].

Importantly, in many of the cancer studies cited in this review, FTY720 was applied at a dosage in excess of that used in multiple sclerosis patients, who currently receive $0.5 \mathrm{mg}$ once-daily dose. The known adverse effects at this dose include: lymphopenia, increased alanine aminotransferase, herpes zoster infection, hypertension, first-dose bradycardia, and first-degree atrioventricular block [239, 246], reviewed in [88]. Higher doses of FTY720 that may be necessary for cancer treatment may be associated with more adverse events or unpredictable off-target effects, and this needs to be addressed by further studies.

At the moment it is unlikely that FTY720 may be used as a monotherapy for any cancer, at least in its pure form. However, a multitude of studies has shown its potentiating effect on many therapies including standard DNA-targeting and antimitotic therapies and $\gamma$-irradiation. Therefore, one of the most important steps in its clinical implementation is finding the key combinations where FTY720 can act in synergy with the currently used therapies inducing sensitisation and overcoming cancer therapy resistance.

Another important step is defining the patient populations that will most benefit from the FTY720 therapy. This could be largely based on the tumour expression of the multiple FTY720 targets described in this review. It may be that some subsets of tumours would be particularly sensitive to this therapy. This approach can be helped by the large scale sequencing studies currently undertaken in several countries with the aim of defining specific cancer mutations/genetic aberrations in large groups of patients. For example it was shown that cancer cells overexpressing pp32r1 or a pp32r1Y140H functional mutant in the ANP32C oncogene that is overexpressed in breast, prostate and pancreatic tumours, may demonstrate enhanced resistance to FTY720 treatment through conserved residue F136, likely to be a key determinant of the FTY720 binding site [247]. However it is not known whether this mutation is present in large human populations.

Overall, FTY720 is a clinically approved therapy for multiple sclerosis and a potent apoptosis inducer and anticancer agent with a proven efficiency in multiple in vitro and in vivo anticancer models. While the clinical transition of FTY720 is currently limited by its immune suppression effects, in our opinion studies aiming at the FTY720 delivery and release together with identifying its key synergetic combinations and relevant patient subsets may lead to its re-evaluation and rapid introduction into the clinic.

\section{FIVE-YEAR VIEW}

We hypothesise that in 5 years the use of targeted FTY720 delivery or its specific non-immunosuppressive analogues will allow its clinical trials for treatment of cancer. Its combinations with other chemotherapies may prove more efficient than its use as a monotherapy.

\section{KEY ISSUES}

FTY720 demonstrates a proven efficacy in multiple in vitro and in vivo cancer models.

FTY720 inhibits sphingosine kinase 1, a protooncogenic enzyme with in vitro and clinical cancer association.

FTY720's has actions on several other molecular targets including protein phosphatase $2 \mathrm{~A}$, the PI3K/Akt pathway, cell cycle regulators, cell transporters, autotaxin and the mitochondrial permeability transition pore.

FTY720 is a FDA-approved drug for multiple sclerosis, which can significantly simplify its clinical implementation for other uses.

Targeted FTY720 delivery and release together with identifying its key synergetic combinations and relevant patient subsets may lead to its rapid introduction into the clinic.

\section{CONFLICT OF INTERESTS}

The authors have no financial, commercial or other relationships of a declarable nature relevant to the materials discussed in the manuscript.

\section{FUNDING}

DP was supported by the Prostate UK grant PG1214. HA was supported by the Deanship of Scientific Research, University of Petra (Amman-Jordan). 


\section{REFERENCES}

1. Morad SA and Cabot MC. Ceramide-orchestrated signalling in cancer cells. Nat Rev Cancer. 2013; 13(1):51-65.

2. Proia RL and Hla T. Emerging biology of sphingosine1-phosphate: its role in pathogenesis and therapy. J Clin Invest. 2015; 125(4):1379-1387.

3. Cuvillier O, Pirianov G, Kleuser B, Vanek PG, Coso OA, Gutkind S and Spiegel S. Suppression of ceramide-mediated programmed cell death by sphingosine-1-phosphate. Nature. 1996; 381(6585):800-803.

4. Hannun YA and Obeid LM. Principles of bioactive lipid signalling: lessons from sphingolipids. Nat Rev Mol Cell Biol. 2008; 9(2):139-150.

5. Takabe K, Paugh SW, Milstien S and Spiegel S. "Insideout" signaling of sphingosine-1-phosphate: therapeutic targets. Pharmacol Rev. 2008; 60(2):181-195.

6. Newton J, Lima S, Maceyka M and Spiegel S. Revisiting the sphingolipid rheostat: Evolving concepts in cancer therapy. Exp Cell Res. 2015; 333(2):195-200.

7. Taha TA, Hannun YA and Obeid LM. Sphingosine kinase: biochemical and cellular regulation and role in disease. $\mathrm{J}$ Biochem Mol Biol. 2006; 39(2):113-131.

8. Pitson SM. Regulation of sphingosine kinase and sphingolipid signaling. Trends Biochem Sci. 2011; 36:97107.

9. Pyne S, Lee SC, Long J and Pyne NJ. Role of sphingosine kinases and lipid phosphate phosphatases in regulating spatial sphingosine 1-phosphate signalling in health and disease. Cell Signal. 2009; 21(1):14-21.

10. Igarashi N, Okada T, Hayashi S, Fujita T, Jahangeer S and Nakamura S. Sphingosine kinase 2 is a nuclear protein and inhibits DNA synthesis. J Biol Chem. 2003; 278(47):4683246839.

11. Pitson SM, Moretti PA, Zebol JR, Xia P, Gamble JR, Vadas MA, D'Andrea RJ and Wattenberg BW. Expression of a catalytically inactive sphingosine kinase mutant blocks agonist-induced sphingosine kinase activation. A dominant-negative sphingosine kinase. J Biol Chem. 2000; 275(43):33945-33950.

12. Pitson SM, Moretti PA, Zebol JR, Lynn HE, Xia P, Vadas MA and Wattenberg BW. Activation of sphingosine kinase 1 by ERK1/2-mediated phosphorylation. Embo J. 2003; 22(20):5491-5500.

13. Tani $\mathrm{M}$, Ito $\mathrm{M}$ and Igarashi $\mathrm{Y}$. Ceramide/sphingosine/ sphingosine 1-phosphate metabolism on the cell surface and in the extracellular space. Cell Signal. 2007; 19(2):229-237.

14. Mizugishi K, Yamashita T, Olivera A, Miller GF, Spiegel $\mathrm{S}$ and Proia RL. Essential role for sphingosine kinases in neural and vascular development. Mol Cell Biol. 2005; 25(24):11113-11121.

15. Pitson SM, Xia P, Leclercq TM, Moretti PA, Zebol JR, Lynn HE, Wattenberg BW and Vadas MA. Phosphorylationdependent translocation of sphingosine kinase to the plasma membrane drives its oncogenic signalling. J Exp Med. 2005; 201(1):49-54.

16. Takabe K and Spiegel S. Export of sphingosine-1-phosphate and cancer progression. J Lipid Res. 2014; 55(9):18391846.

17. Payne SG, Milstien S and Spiegel S. Sphingosine-1phosphate: dual messenger functions. FEBS Lett. 2002; 531(1):54-57.

18. Verzijl D, Peters SL and Alewijnse AE. Sphingosine1-phosphate receptors: zooming in on ligand-induced intracellular trafficking and its functional implications. Mol Cells. 2010; 29(2):99-104.

19. Oo ML, Thangada S, Wu MT, Liu CH, Macdonald TL, Lynch KR, Lin CY and Hla T. Immunosuppressive and antiangiogenic sphingosine 1-phosphate receptor-1 agonists induce ubiquitinylation and proteasomal degradation of the receptor. J Biol Chem. 2007; 282(12):9082-9089.

20. Strub GM, Maceyka M, Hait NC, Milstien S and Spiegel S. Extracellular and intracellular actions of sphingosine-1phosphate. Adv Exp Med Biol. 2010; 688:141-155.

21. Hait NC, Allegood J, Maceyka M, Strub GM, Harikumar KB, Singh SK, Luo C, Marmorstein R, Kordula T, Milstien $\mathrm{S}$ and Spiegel S. Regulation of histone acetylation in the nucleus by sphingosine-1-phosphate. Science. 2009; 325(5945):1254-1257.

22. Alvarez SE, Harikumar KB, Hait NC, Allegood J, Strub GM, Kim EY, Maceyka M, Jiang H, Luo C, Kordula T, Milstien S and Spiegel S. Sphingosine-1-phosphate is a missing cofactor for the E3 ubiquitin ligase TRAF2. Nature. 2010; 465(7301):1084-1088.

23. Beckham TH, Cheng JC, Marrison ST, Norris JS and Liu X. Interdiction of sphingolipid metabolism to improve standard cancer therapies. Adv Cancer Res. 2013; 117:1-36.

24. Johnson KR, Johnson KY, Crellin HG, Ogretmen B, Boylan AM, Harley RA and Obeid LM. Immunohistochemical distribution of sphingosine kinase 1 in normal and tumor lung tissue. J Histochem Cytochem. 2005; 53(9):11591166.

25. Van Brocklyn JR, Jackson CA, Pearl DK, Kotur MS, Snyder PJ and Prior TW. Sphingosine kinase-1 expression correlates with poor survival of patients with glioblastoma multiforme: roles of sphingosine kinase isoforms in growth of glioblastoma cell lines. J Neuropathol Exp Neurol. 2005; 64(8):695-705.

26. Bayerl MG, Bruggeman RD, Conroy EJ, Hengst JA, King TS, Jimenez M, Claxton DF and Yun JK. Sphingosine kinase 1 protein and mRNA are overexpressed in nonHodgkin lymphomas and are attractive targets for novel pharmacological interventions. Leuk Lymphoma. 2008; 49(5):948-954.

27. French KJ, Schrecengost RS, Lee BD, Zhuang Y, Smith SN, Eberly JL, Yun JK and Smith CD. Discovery and evaluation of inhibitors of human sphingosine kinase. Cancer Res. 2003; 63(18):5962-5969. 
28. Watson C, Long JS, Orange C, Tannahill CL, Mallon E, McGlynn LM, Pyne S, Pyne NJ and Edwards J. High expression of sphingosine 1-phosphate receptors, S1P1 and S1P3, sphingosine kinase 1, and extracellular signalregulated kinase-1/2 is associated with development of tamoxifen resistance in estrogen receptor-positive breast cancer patients. The American journal of pathology. 2010; 177(5):2205-2215.

29. Li J, Guan HY, Gong LY, Song LB, Zhang N, Wu J, Yuan J, Zheng YJ, Huang ZS and Li M. Clinical significance of sphingosine kinase-1 expression in human astrocytomas progression and overall patient survival. Clin Cancer Res. 2008; 14(21):6996-7003.

30. Ruckhaberle E, Rody A, Engels K, Gaetje R, von Minckwitz G, Schiffmann S, Grosch S, Geisslinger G, Holtrich U, Karn T and Kaufmann M. Microarray analysis of altered sphingolipid metabolism reveals prognostic significance of sphingosine kinase 1 in breast cancer. Breast Cancer Res Treat. 2008; 112(1):41-52.

31. Malavaud B, Pchejetski D, Mazerolles C, de Paiva GR, Calvet C, Doumerc N, Pitson S, Rischmann P and Cuvillier O. Sphingosine kinase-1 activity and expression in human prostate cancer resection specimens. Eur J Cancer. 2010.

32. Li W, Yu CP, Xia JT, Zhang L, Weng GX, Zheng HQ, Kong QL, Hu LJ, Zeng MS, Zeng YX, Li M, Li J and Song LB. Sphingosine kinase 1 is associated with gastric cancer progression and poor survival of patients. Clin Cancer Res. 2009; 15(4):1393-1399.

33. Song L, Xiong H, Li M, Liao WT, Wang L and Wu J. Sphingosine kinase-1 Enhances Resistance to Apoptosis through Activation of PI3K/Akt/NF-\{kappa\}B Pathway in Human Non-small Cell Lung Cancer. Clin Cancer Res. 2011; 17:1839-49.

34. Liu G, Zheng H, Zhang Z, Wu Z, Xiong H, Li J and Song L. Overexpression of sphingosine kinase 1 is associated with salivary gland carcinoma progression and might be a novel predictive marker for adjuvant therapy. BMC Cancer. 2010; 10:495.

35. Facchinetti MM, Gandini NA, Fermento ME, SterinSpeziale NB, Ji Y, Patel V, Gutkind JS, Rivadulla MG and Curino AC. The Expression of Sphingosine Kinase-1 in Head and Neck Carcinoma. Cells Tissues Organs. 2010; 192:314-24.

36. Sinha UK, Schorn VJ, Hochstim C, Chinn SB, Zhu S and Masood R. Increased radiation sensitivity of head and neck squamous cell carcinoma with sphingosine kinase 1 inhibition. Head Neck. 2011; 33:178-88.

37. Xia P, Gamble JR, Wang L, Pitson SM, Moretti PA, Wattenberg BW, D'Andrea RJ and Vadas MA. An oncogenic role of sphingosine kinase. Curr Biol. 2000; 10(23):1527-1530.

38. Loveridge C, Tonelli F, Leclercq T, Lim KG, Long JS, Berdyshev E, Tate RJ, Natarajan V, Pitson SM, Pyne NJ and Pyne S. The sphingosine kinase 1 inhibitor 2-(p-hydroxyanilino)-4-(p-chlorophenyl)thiazole induces proteasomal degradation of sphingosine kinase 1 in mammalian cells. The Journal of biological chemistry. 2010; 285(50):38841-38852.

39. Dayon A, Brizuela L, Martin C, Mazerolles C, Pirot N, Doumerc N, Nogueira L, Golzio M, Teissie J, Serre G, Rischmann P, Malavaud B and Cuvillier O. Sphingosine kinase-1 is central to androgen-regulated prostate cancer growth and survival. PLoS One. 2009; 4(11):e8048.

40. Pchejetski D, Golzio M, Bonhoure E, Calvet C, Doumerc N, Garcia V, Mazerolles C, Rischmann P, Teissie J, Malavaud $\mathrm{B}$ and Cuvillier O. Sphingosine kinase-1 as a chemotherapy sensor in prostate adenocarcinoma cell and mouse models. Cancer Res. 2005; 65(24):11667-11675.

41. Bonhoure E, Pchejetski D, Aouali N, Morjani H, Levade T, Kohama T and Cuvillier O. Overcoming MDR-associated chemoresistance in HL-60 acute myeloid leukemia cells by targeting sphingosine kinase-1. Leukemia. 2006; 20(1):95102.

42. Leroux ME, Auzenne E, Evans R, Hail N, Jr., Spohn W, Ghosh SC, Farquhar D, McDonnell T and Klostergaard J. Sphingolipids and the sphingosine kinase inhibitor, SKI II, induce BCL-2-independent apoptosis in human prostatic adenocarcinoma cells. Prostate. 2007; 67(15):1699-1717.

43. Akao Y, Banno Y, Nakagawa Y, Hasegawa N, Kim TJ, Murate T, Igarashi Y and Nozawa Y. High expression of sphingosine kinase 1 and S1P receptors in chemotherapyresistant prostate cancer PC3 cells and their camptothecininduced up-regulation. Biochem Biophys Res Commun. 2006; 342(4):1284-1290.

44. Pchejetski D, Bohler T, Brizuela L, Sauer L, Doumerc N, Golzio M, Salunkhe V, Teissie J, Malavaud B, Waxman J and Cuvillier O. FTY720 (Fingolimod) Sensitizes Prostate Cancer Cells to Radiotherapy by Inhibition of Sphingosine Kinase-1. Cancer research. 2010; 70:8651-61.

45. Gude DR, Alvarez SE, Paugh SW, Mitra P, Yu J, Griffiths R, Barbour SE, Milstien S and Spiegel S. Apoptosis induces expression of sphingosine kinase 1 to release sphingosine1-phosphate as a "come-and-get-me" signal. Faseb J. 2008; 22(8):2629-2638.

46. Bektas M, Jolly PS, Muller C, Eberle J, Spiegel S and Geilen CC. Sphingosine kinase activity counteracts ceramide-mediated cell death in human melanoma cells: role of Bcl-2 expression. Oncogene. 2005; 24(1):178-187.

47. Nava VE, Hobson JP, Murthy S, Milstien S and Spiegel $\mathrm{S}$. Sphingosine kinase type 1 promotes estrogen-dependent tumorigenesis of breast cancer MCF-7 cells. Exp Cell Res. 2002; 281(1):115-127.

48. Sukocheva OA, Wang L, Albanese N, Pitson SM, Vadas MA and Xia P. Sphingosine kinase transmits estrogen signaling in human breast cancer cells. Mol Endocrinol. 2003; 17(10):2002-2012.

49. Melendez AJ and Ibrahim FB. Antisense knockdown of sphingosine kinase 1 in human macrophages inhibits C5a receptor-dependent signal transduction, $\mathrm{Ca} 2+$ signals, 
enzyme release, cytokine production, and chemotaxis. J Immunol. 2004; 173(3):1596-1603.

50. Pettus BJ, Bielawski J, Porcelli AM, Reames DL, Johnson KR, Morrow J, Chalfant CE, Obeid LM and Hannun YA. The sphingosine kinase 1/sphingosine-1-phosphate pathway mediates COX-2 induction and PGE2 production in response to TNF-alpha. Faseb J. 2003; 17(11):1411-1421.

51. Weigert A, Tzieply N, von Knethen A, Johann AM, Schmidt H, Geisslinger $G$ and Brune B. Tumor cell apoptosis polarizes macrophages role of sphingosine-1phosphate. Mol Biol Cell. 2007; 18(10):3810-3819.

52. Xie B, Shen J, Dong A, Rashid A, Stoller G and Campochiaro PA. Blockade of sphingosine-1-phosphate reduces macrophage influx and retinal and choroidal neovascularization. J Cell Physiol. 2009; 218(1):192-198.

53. Condeelis J and Pollard JW. Macrophages: obligate partners for tumor cell migration, invasion, and metastasis. Cell. 2006; 124(2):263-266.

54. Karin M and Greten FR. NF-kappaB: linking inflammation and immunity to cancer development and progression. Nat Rev Immunol. 2005; 5(10):749-759.

55. Johann AM, Weigert A, Eberhardt W, Kuhn AM, Barra V, von Knethen A, Pfeilschifter JM and Brune B. Apoptotic cell-derived sphingosine-1-phosphate promotes HuRdependent cyclooxygenase-2 mRNA stabilization and protein expression. J Immunol. 2008; 180(2):1239-1248.

56. Xia P, Gamble JR, Rye KA, Wang L, Hii CS, Cockerill P, Khew-Goodall Y, Bert AG, Barter PJ and Vadas MA. Tumor necrosis factor-alpha induces adhesion molecule expression through the sphingosine kinase pathway. Proc Natl Acad Sci U S A. 1998; 95(24):14196-14201.

57. Radeff-Huang J, Seasholtz TM, Chang JW, Smith JM and Walsh CT. TNF-alpha -stimulated cell proliferation is mediated through sphingosine kinase-dependent AKT activation and cyclin D expression. J Biol Chem. 2007; 282:863-70.

58. Xia P, Wang L, Moretti PA, Albanese N, Chai F, Pitson SM, D'Andrea RJ, Gamble JR and Vadas MA. Sphingosine kinase interacts with TRAF2 and dissects tumor necrosis factor-alpha signaling. J Biol Chem. 2002; 277(10):79968003 .

59. Xiong Y, Lee HJ, Mariko B, Lu YC, Dannenberg AJ, Haka AS, Maxfield FR, Camerer E, Proia RL and Hla T. Sphingosine kinases are not required for inflammatory responses in macrophages. J Biol Chem. 2013; 288(45):32563-32573.

60. Shida D, Fang X, Kordula T, Takabe K, Lepine S, Alvarez SE, Milstien S and Spiegel S. Cross-talk between LPA1 and epidermal growth factor receptors mediates up-regulation of sphingosine kinase 1 to promote gastric cancer cell motility and invasion. Cancer Res. 2008; 68(16):6569-6577.

61. Hobson JP, Rosenfeldt HM, Barak LS, Olivera A, Poulton $\mathrm{S}$, Caron MG, Milstien S and Spiegel S. Role of the sphingosine-1-phosphate receptor EDG-1 in PDGF-induced cell motility. Science. 2001; 291(5509):1800-1803.

62. Takuwa Y. Subtype-specific differential regulation of Rho family $G$ proteins and cell migration by the Edg family sphingosine-1-phosphate receptors. Biochim Biophys Acta. 2002; 1582(1-3):112-120.

63. Visentin B, Vekich JA, Sibbald BJ, Cavalli AL, Moreno KM, Matteo RG, Garland WA, Lu Y, Yu S, Hall HS, Kundra V, Mills GB and Sabbadini RA. Validation of an anti-sphingosine-1-phosphate antibody as a potential therapeutic in reducing growth, invasion, and angiogenesis in multiple tumor lineages. Cancer Cell. 2006; 9(3):225238.

64. Doll F, Pfeilschifter J and Huwiler A. Prolactin upregulates sphingosine kinase-1 expression and activity in the human breast cancer cell line MCF7 and triggers enhanced proliferation and migration. Endocr Relat Cancer. 2007; 14(2):325-335.

65. Kaneider NC, Djanani A, Fischer-Colbrie R and Wiedermann CJ. Sphingosine kinase-dependent directional migration of leukocytes in response to phorbol ester. Biochem Biophys Res Commun. 2002; 297(4):806-810.

66. Maceyka M, Alvarez SE, Milstien S and Spiegel S. Filamin A links sphingosine kinase 1 and sphingosine-1-phosphate receptor 1 at lamellipodia to orchestrate cell migration. Mol Cell Biol. 2008; 28(18):5687-5697.

67. Schwalm S, Doll F, Romer I, Bubnova S, Pfeilschifter J and Huwiler A. Sphingosine kinase-1 is a hypoxia-regulated gene that stimulates migration of human endothelial cells. Biochem Biophys Res Commun. 2008; 368(4):1020-1025.

68. Bergelin N, Blom T, Heikkila J, Lof C, Alam C, Balthasar S, Slotte JP, Hinkkanen A and Tornquist K. Sphingosine kinase as an oncogene: autocrine sphingosine 1-phosphate modulates ML-1 thyroid carcinoma cell migration by a mechanism dependent on protein kinase C-alpha and ERK1/2. Endocrinology. 2009; 150(5):2055-2063.

69. Hla T. Signaling and biological actions of sphingosine 1-phosphate. Pharmacol Res. 2003; 47(5):401-407.

70. Liu Y, Wada R, Yamashita T, Mi Y, Deng CX, Hobson JP, Rosenfeldt HM, Nava VE, Chae SS, Lee MJ, Liu CH, Hla T, Spiegel S and Proia RL. Edg-1, the G protein-coupled receptor for sphingosine-1-phosphate, is essential for vascular maturation. J Clin Invest. 2000; 106(8):951-961.

71. Matloubian M, Lo CG, Cinamon G, Lesneski MJ, Xu Y, Brinkmann V, Allende ML, Proia RL and Cyster JG. Lymphocyte egress from thymus and peripheral lymphoid organs is dependent on S1P receptor 1. Nature. 2004; 427(6972):355-360.

72. Paik JH, Chae S, Lee MJ, Thangada S and Hla T. Sphingosine 1-phosphate-induced endothelial cell migration requires the expression of EDG-1 and EDG-3 receptors and Rho-dependent activation of alpha vbeta3- and beta1containing integrins. J Biol Chem. 2001; 276(15):1183011837.

73. Hashimoto M, Wang X, Mao L, Kobayashi T, Kawasaki S, 
Mori N, Toews ML, Kim HJ, Cerutis R, Liu X and Rennard SI. Sphingosine 1-phosphate Potentiates Human Lung Fibroblast Chemotaxis through the S1P2 Receptor. Am J Respir Cell Mol Biol. 2008; 39:356-63.

74. Goparaju SK, Jolly PS, Watterson KR, Bektas M, Alvarez S, Sarkar S, Mel L, Ishii I, Chun J, Milstien S and Spiegel $\mathrm{S}$. The S1P2 receptor negatively regulates platelet-derived growth factor-induced motility and proliferation. Mol Cell Biol. 2005; 25(10):4237-4249.

75. Sanchez T, Thangada S, Wu MT, Kontos CD, Wu D, $\mathrm{Wu} \mathrm{H}$ and Hla T. PTEN as an effector in the signaling of antimigratory G protein-coupled receptor. Proc Natl Acad Sci U S A. 2005; 102(12):4312-4317.

76. Sugimoto N, Takuwa N, Okamoto H, Sakurada S and Takuwa Y. Inhibitory and stimulatory regulation of Rac and cell motility by the G12/13-Rho and Gi pathways integrated downstream of a single $G$ protein-coupled sphingosine-1-phosphate receptor isoform. Mol Cell Biol. 2003; 23(5):1534-1545.

77. Bryan L, Paugh BS, Kapitonov D, Wilczynska KM, Alvarez SM, Singh SK, Milstien S, Spiegel S and Kordula T. Sphingosine-1-phosphate and interleukin-1 independently regulate plasminogen activator inhibitor-1 and urokinasetype plasminogen activator receptor expression in glioblastoma cells: implications for invasiveness. Mol Cancer Res. 2008; 6(9):1469-1477.

78. Duan HF, Wu CT, Lu Y, Wang H, Liu HJ, Zhang QW, Jia $\mathrm{XX}$, Lu ZZ and Wang LS. Sphingosine kinase activation regulates hepatocyte growth factor induced migration of endothelial cells. Exp Cell Res. 2004; 298(2):593-601.

79. Licht T, Tsirulnikov L, Reuveni H, Yarnitzky T and BenSasson SA. Induction of pro-angiogenic signaling by a synthetic peptide derived from the second intracellular loop of S1P3 (EDG3). Blood. 2003; 102(6):2099-2107.

80. Liu F, Verin AD, Wang P, Day R, Wersto RP, Chrest FJ, English DK and Garcia JG. Differential regulation of sphingosine-1-phosphate- and VEGF-induced endothelial cell chemotaxis. Involvement of G(ialpha2)-linked Rho kinase activity. Am J Respir Cell Mol Biol. 2001; 24(6):711-719.

81. Wu W, Shu X, Hovsepyan H, Mosteller RD and Broek D. VEGF receptor expression and signaling in human bladder tumors. Oncogene. 2003; 22(22):3361-3370.

82. Chae SS, Paik JH, Furneaux H and Hla T. Requirement for sphingosine 1-phosphate receptor-1 in tumor angiogenesis demonstrated by in vivo RNA interference. J Clin Invest. 2004; 114(8):1082-1089.

83. Anelli V, Gault CR, Snider AJ and Obeid LM. Role of sphingosine kinase-1 in paracrine/transcellular angiogenesis and lymphangiogenesis in vitro. FASEB J. 2010; 24(8):2727-2738.

84. Brizuela L, Dayon A, Doumerc N, Ader I, Golzio M, Izard JC, Hara Y, Malavaud B and Cuvillier O. The sphingosine kinase-1 survival pathway is a molecular target for the tumor-suppressive tea and wine polyphenols in prostate cancer. FASEB J. 2010; 24(10):3882-3894.

85. Min J, Van Veldhoven PP, Zhang L, Hanigan $\mathrm{MH}$, Alexander $\mathrm{H}$ and Alexander S. Sphingosine-1-phosphate lyase regulates sensitivity of human cells to select chemotherapy drugs in a p38-dependent manner. Mol Cancer Res. 2005; 3(5):287-296.

86. Pchejetski D, Doumerc N, Golzio M, Naymark M, Teissie J, Kohama T, Waxman J, Malavaud B and Cuvillier O. Chemosensitizing effects of sphingosine kinase-1 inhibition in prostate cancer cell and animal models. Mol Cancer Ther. 2008; 7(7):1836-1845.

87. Sauer L, Nunes J, Salunkhe V, Skalska L, Kohama T, Cuvillier O, Waxman J and Pchejetski D. Sphingosine kinase 1 inhibition sensitizes hormone-resistant prostate cancer to docetaxel. International journal of cancer. 2009; 125:2728-36.

88. Pchejetski D, Bohler T, Brizuela L, Sauer L, Doumerc N, Golzio M, Salunkhe V, Teissie J, Malavaud B, Waxman J and Cuvillier O. FTY720 (fingolimod) sensitizes prostate cancer cells to radiotherapy by inhibition of sphingosine kinase-1. Cancer Res. 2010; 70(21):8651-8661.

89. Sukocheva O, Wang L, Verrier E, Vadas MA and Xia P. Restoring endocrine response in breast cancer cells by inhibition of the sphingosine kinase-1 signaling pathway. Endocrinology. 2009; 150(10):4484-4492.

90. Huwiler A, Kotelevets N, Xin C, Pastukhov O, Pfeilschifter $\mathrm{J}$ and Zangemeister-Wittke U. Loss of sphingosine kinase-1 in carcinoma cells increases formation of reactive oxygen species and sensitivity to doxorubicin-induced DNA damage. Br J Pharmacol. 2011; 162(2):532-543.

91. Jung ID, Lee JS, Kim YJ, Jeong YI, Lee CM, Baumruker T, Billlich A, Banno Y, Lee MG, Ahn SC, Park WS, Han $\mathrm{J}$ and Park YM. Sphingosine kinase inhibitor suppresses a Th1 polarization via the inhibition of immunostimulatory activity in murine bone marrow-derived dendritic cells. Int Immunol. 2007; 19(4):411-426.

92. Bruno AP, Laurent G, Averbeck D, Demur C, Bonnet J, Bettaieb A, Levade T and Jaffrezou JP. Lack of ceramide generation in TF-1 human myeloid leukemic cells resistant to ionizing radiation. Cell Death Differ. 1998; 5(2):172-182.

93. Chmura SJ, Nodzenski E, Beckett MA, Kufe DW, Quintans $\mathrm{J}$ and Weichselbaum RR. Loss of ceramide production confers resistance to radiation-induced apoptosis. Cancer Res. 1997; 57(7):1270-1275.

94. Edsall LC, Van Brocklyn JR, Cuvillier O, Kleuser B and Spiegel S. N,N-Dimethylsphingosine is a potent competitive inhibitor of sphingosine kinase but not of protein kinase $\mathrm{C}$ : modulation of cellular levels of sphingosine 1-phosphate and ceramide. Biochemistry. 1998; 37(37):12892-12898.

95. Sweeney EA, Sakakura C, Shirahama T, Masamune A, Ohta H, Hakomori S and Igarashi Y. Sphingosine and its methylated derivative N,N-dimethylsphingosine (DMS) induce apoptosis in a variety of human cancer cell lines. Int 
J Cancer. 1996; 66(3):358-366.

96. Cuvillier O. Downregulating sphingosine kinase-1 for cancer therapy. Expert Opin Ther Targets. 2008; 12(8):1009-1020.

97. Endo K, Igarashi Y, Nisar M, Zhou Q and Hakomori S. Cell membrane signaling as target in cancer therapy: inhibitory effect of N, N-dimethyl and N, N, N-trimethyl sphingosine derivatives on in vitro and in vivo growth of human tumor cells in nude mice. Cancer research. 1991; 51(6):1613.

98. Okoshi H, Hakomori S, Nisar M, Zhou Q, Kimura S, Tashiro $\mathrm{K}$ and Igarashi $\mathrm{Y}$. Cell membrane signaling as target in cancer therapy II: Inhibitory effect of N, N, $\mathrm{N}$-trimethylsphingosine on metastatic potential of murine B16 melanoma cell line through blocking of tumor celldependent platelet aggregation. Cancer research. 1991; 51(22):6019.

99. Nava VE, Cuvillier O, Edsall LC, Kimura K, Milstien S, Gelmann EP and Spiegel S. Sphingosine enhances apoptosis of radiation-resistant prostate cancer cells. Cancer Res. 2000; 60(16):4468-4474.

100. Merrill AH, Jr., Schmelz EM, Dillehay DL, Spiegel S, Shayman JA, Schroeder JJ, Riley RT, Voss KA and Wang E. Sphingolipids - the enigmatic lipid class: biochemistry, physiology, and pathophysiology. Toxicol Appl Pharmacol. 1997; 142(1):208-225.

101. Kono K, Sugiura M and Kohama T. Inhibition of recombinant sphingosine kinases by novel inhibitors of microbial origin, F-12509A and B-5354c. J Antibiot (Tokyo). 2002; 55(1):99-103.

102. Bonhoure E, Lauret A, Barnes D, Martin C, Malavaud B, Kohama T, Melo J and Cuvillier O. Sphingosine kinase-1 is a downstream regulator of imatinib-induced apoptosis in chronic myeloid leukemia cells. Leukemia. 2008; 22(5):971-979.

103. French K, Upson J, Keller S, Zhuang Y, Yun J and Smith C. Antitumor activity of sphingosine kinase inhibitors. Journal of Pharmacology and Experimental Therapeutics. 2006; 318(2):596.

104. Tonelli F, Alossaimi M, Williamson L, Tate RJ, Watson DG, Chan E, Bittman R, Pyne NJ and Pyne S. The sphingosine kinase inhibitor 2-(p-hyroxyanilino)-4(p-chlorophenyl)thiazole reduces androgen receptor expression via an oxidative stress-dependent mechanism. Br J Pharmacol. 2013; 168(6):1497-1505.

105. Paugh SW, Paugh BS, Rahmani M, Kapitonov D, Almenara JA, Kordula T, Milstien S, Adams JK, Zipkin RE, Grant S and Spiegel S. A selective sphingosine kinase 1 inhibitor integrates multiple molecular therapeutic targets in human leukemia. Blood. 2008; 112:1382-91.

106. Xiang Y, Asmussen G, Booker M, Hirth B, Kane JL, Jr., Liao J, Noson KD and Yee C. Discovery of novel sphingosine kinase 1 inhibitors. Bioorg Med Chem Lett. 2009; 19(21):6119-6121.

107. Kennedy AJ, Mathews TP, Kharel Y, Field SD, Moyer
ML, East JE, Houck JD, Lynch KR and Macdonald TL. Development of amidine-based sphingosine kinase 1 nanomolar inhibitors and reduction of sphingosine 1-phosphate in human leukemia cells. J Med Chem. 2011; 54(10):3524-3548.

108. Tonelli F, Lim KG, Loveridge C, Long J, Pitson SM, Tigyi G, Bittman R, Pyne S and Pyne NJ. FTY720 and (S)-FTY720 vinylphosphonate inhibit sphingosine kinase 1 and promote its proteasomal degradation in human pulmonary artery smooth muscle, breast cancer and androgen-independent prostate cancer cells. Cell Signal. 2010; 22(10):1536-1542.

109. Sharma AK. Sphingo-guanidines and their use as inhibitors of sphingosine kinase (WO2010078247). Expert Opin Ther Pat. 2011; 21(5):807-812.

110. Hengst J, Wang X, Sk U, Sharma A, Amin S and Yun J. Development of a Sphingosine Kinase 1 Specific SmallMolecule Inhibitor. Bioorganic \& Medicinal Chemistry Letters. 2010; 20:7498-502.

111. Banno Y, Kato M, Hara A and Nozawa Y. Evidence for the presence of multiple forms of Sph kinase in human platelets. Biochemical Journal. 1998; 335(Pt 2):301.

112. Dickson MA, Carvajal RD, Merrill AH, Jr., Gonen M, Cane LM and Schwartz GK. A phase I clinical trial of safingol in combination with cisplatin in advanced solid tumors. Clin Cancer Res. 2011; 17(8):2484-2492.

113. Schnute ME, McReynolds MD, Kasten T, Yates M, Jerome G, Rains JW, Hall T, Chrencik J, Kraus M, Cronin CN, Saabye M, Highkin MK, Broadus R, Ogawa S, Cukyne $\mathrm{K}$, Zawadzke LE, et al. Modulation of cellular S1P levels with a novel, potent and specific inhibitor of sphingosine kinase-1. Biochem J. 2012; 444(1):79-88.

114. Kharel Y, Mathews TP, Gellett AM, Tomsig JL, Kennedy PC, Moyer ML, Macdonald TL and Lynch KR. Sphingosine kinase type 1 inhibition reveals rapid turnover of circulating sphingosine 1-phosphate. Biochem J. 2011; 440(3):345353.

115. Rex K, Jeffries S, Brown ML, Carlson T, Coxon A, Fajardo F, Frank B, Gustin D, Kamb A, Kassner PD, Li S, Li Y, Morgenstern K, Plant M, Quon K, Ruefli-Brasse A, et al. Sphingosine kinase activity is not required for tumor cell viability. PLoS One. 2013; 8(7):e68328.

116. Lee JW, Ryu JY, Yoon G, Jeon HK, Cho YJ, Choi JJ, Song SY, Do IG, Lee YY, Kim TJ, Choi CH, Kim BG and Bae DS. Sphingosine kinase 1 as a potential therapeutic target in epithelial ovarian cancer. Int J Cancer. 2015; 137(1):221229.

117. Datta A, Loo SY, Huang B, Wong L, Tan SS, Tan TZ, Lee SC, Thiery JP, Lim YC, Yong WP, Lam Y, Kumar AP and Yap CT. SPHK1 regulates proliferation and survival responses in triple-negative breast cancer. Oncotarget. 2014; 5(15):5920-5933. doi 10.18632/oncotarget.1874.

118. Martin JL, de Silva HC, Lin MZ, Scott CD and Baxter RC. Inhibition of insulin-like growth factor-binding protein-3 
signaling through sphingosine kinase-1 sensitizes triplenegative breast cancer cells to EGF receptor blockade. Molecular cancer therapeutics. 2014; 13(2):316-328.

119. Pchejetski D, Golzio M, Bonhoure E, Calvet C, Doumerc N, Garcia V, Mazerolles C, Rischmann P, Teissie J, Malavaud $\mathrm{B}$ and Cuvillier O. Sphingosine kinase-1 as a chemotherapy sensor in prostate adenocarcinoma cell and mouse models. Cancer research. 2005; 65(24):11667-11675.

120. Fujita T, Inoue K, Yamamoto S, Ikumoto T, Sasaki S, Toyama R, Chiba K, Hoshino Y and Okumoto T. Fungal metabolites. Part 11. A potent immunosuppressive activity found in Isaria sinclairii metabolite. The Journal of antibiotics. 1994; 47(2):208-215.

121. Chiba K, Yanagawa Y, Masubuchi Y, Kataoka H, Kawaguchi T, Ohtsuki M and Hoshino Y. FTY720, a novel immunosuppressant, induces sequestration of circulating mature lymphocytes by acceleration of lymphocyte homing in rats. I. FTY720 selectively decreases the number of circulating mature lymphocytes by acceleration of lymphocyte homing. Journal of immunology. 1998; 160(10):5037-5044.

122. Lim KG, Tonelli F, Li Z, Lu X, Bittman R, Pyne S and Pyne NJ. FTY720 analogues as sphingosine kinase 1 inhibitors: enzyme inhibition kinetics, allosterism, proteasomal degradation, and actin rearrangement in MCF-7 breast cancer cells. J Biol Chem. 2011; 286(21):18633-18640.

123. Vessey DA, Kelley M, Zhang J, Li L, Tao R and Karliner JS. Dimethylsphingosine and FTY720 inhibit the SK1 form but activate the SK2 form of sphingosine kinase from rat heart. J Biochem Mol Toxicol. 2007; 21(5):273-279.

124. Kharel Y, Lee S, Snyder AH, Sheasley-O'neill S L, Morris MA, Setiady Y, Zhu R, Zigler MA, Burcin TL, Ley K, Tung KS, Engelhard VH, Macdonald TL, Pearson-White S and Lynch KR. Sphingosine kinase 2 is required for modulation of lymphocyte traffic by FTY720. The Journal of biological chemistry. 2005; 280(44):36865-36872.

125. Paugh SW, Payne SG, Barbour SE, Milstien S and Spiegel S. The immunosuppressant FTY720 is phosphorylated by sphingosine kinase type 2. FEBS letters. 2003; 554(12):189-193.

126. Billich A, Bornancin F, Devay P, Mechtcheriakova $\mathrm{D}$, Urtz $\mathrm{N}$ and Baumruker T. Phosphorylation of the immunomodulatory drug FTY720 by sphingosine kinases. The Journal of biological chemistry. 2003; 278(48):4740847415.

127. Sanchez T, Estrada-Hernandez T, Paik JH, Wu MT, Venkataraman K, Brinkmann V, Claffey K and Hla T. Phosphorylation and action of the immunomodulator FTY720 inhibits vascular endothelial cell growth factorinduced vascular permeability. J Biol Chem. 2003; 278(47):47281-47290.

128. Hogenauer K, Billich A, Pally C, Streiff M, Wagner T, Welzenbach $\mathrm{K}$ and Nussbaumer P. Phosphorylation by sphingosine kinase 2 is essential for in vivo potency of FTY720 analogues. ChemMedChem. 2008; 3(7):1027-
1029.

129. Sanna MG, Wang SK, Gonzalez-Cabrera PJ, Don A, Marsolais D, Matheu MP, Wei SH, Parker I, Jo E, Cheng WC, Cahalan MD, Wong CH and Rosen H. Enhancement of capillary leakage and restoration of lymphocyte egress by a chiral S1P1 antagonist in vivo. Nat Chem Biol. 2006; 2(8):434-441.

130. Budde K, Schutz M, Glander P, Peters H, Waiser J, Liefeldt L, Neumayer HH and Bohler T. FTY720 (fingolimod) in renal transplantation. Clin Transplant. 2006; 20 Suppl 17:17-24.

131. Chiba K. FTY720, a new class of immunomodulator, inhibits lymphocyte egress from secondary lymphoid tissues and thymus by agonistic activity at sphingosine 1-phosphate receptors. Pharmacol Ther. 2005; 108(3):308319.

132. Jo E, Sanna MG, Gonzalez-Cabrera PJ, Thangada S, Tigyi G, Osborne DA, Hla T, Parrill AL and Rosen H. S1P1-selective in vivo-active agonists from highthroughput screening: off-the-shelf chemical probes of receptor interactions, signaling, and fate. Chem Biol. 2005; 12(6):703-715.

133. Lo CG, Xu Y, Proia RL and Cyster JG. Cyclical modulation of sphingosine-1-phosphate receptor 1 surface expression during lymphocyte recirculation and relationship to lymphoid organ transit. J Exp Med. 2005; 201(2):291-301.

134. Hla T and Brinkmann V. Sphingosine 1-phosphate (S1P): Physiology and the effects of S1P receptor modulation. Neurology. 2011; 76(8 Suppl 3):S3-8.

135. Mehling M, Brinkmann V, Antel J, Bar-Or A, Goebels N, Vedrine C, Kristofic C, Kuhle J, Lindberg RL and Kappos L. FTY720 therapy exerts differential effects on $\mathrm{T}$ cell subsets in multiple sclerosis. Neurology. 2008; 71(16):1261-1267.

136. Strader CR, Pearce CJ and Oberlies NH. Fingolimod (FTY720): a recently approved multiple sclerosis drug based on a fungal secondary metabolite. Journal of natural products. 2011; 74(4):900-907.

137. Egom EE, Ke Y, Musa H, Mohamed TM, Wang T, Cartwright E, Solaro RJ and Lei M. FTY720 prevents ischemia/reperfusion injury-associated arrhythmias in an ex vivo rat heart model via activation of Pak1/Akt signaling. Journal of molecular and cellular cardiology. 2010; 48(2):406-414.

138. Egom EE, Mohamed TM, Mamas MA, Shi Y, Liu W, Chirico D, Stringer SE, Ke Y, Shaheen M, Wang T, Chacko S, Wang X, Solaro RJ, Fath-Ordoubadi F, Cartwright EJ and Lei M. Activation of Pak1/Akt/eNOS signaling following sphingosine-1-phosphate release as part of a mechanism protecting cardiomyocytes against ischemic cell injury. American journal of physiology Heart and circulatory physiology. 2011; 301(4):H1487-1495.

139. Jin ZQ, Goetzl EJ and Karliner JS. Sphingosine kinase activation mediates ischemic preconditioning in murine 
heart. Circulation. 2004; 110(14):1980-1989.

140. Pchejetski D, Kunduzova O, Dayon A, Calise D, Seguelas MH, Leducq N, Seif I, Parini A and Cuvillier O. Oxidative stress-dependent sphingosine kinase-1 inhibition mediates monoamine oxidase A-associated cardiac cell apoptosis. Circ Res. 2007; 100(1):41-49.

141. Skerjanec A, Tedesco H, Neumayer HH, Cole E, Budde K, Hsu CH and Schmouder R. FTY720, a novel immunomodulator in de novo kidney transplant patients: pharmacokinetics and exposure-response relationship. J Clin Pharmacol. 2005; 45(11):1268-1278.

142. Braun WE. Renal transplantation: basic concepts and evolution of therapy. Journal of clinical apheresis. 2003; 18(3):141-152.

143. Suzuki S, Li XK, Enosawa S and Shinomiya T. A new immunosuppressant, FTY720, induces bcl-2-associated apoptotic cell death in human lymphocytes. Immunology. 1996; 89(4):518-523.

144. Nagahara Y, Enosawa S, Ikekita M, Suzuki S and Shinomiya T. Evidence that FTY720 induces T cell apoptosis in vivo. Immunopharmacology. 2000; 48(1):7585.

145. Yoshino T, Tabunoki H, Sugiyama S, Ishii K, Kim SU and Satoh J. Non-phosphorylated FTY720 induces apoptosis of human microglia by activating SREBP2. Cellular and molecular neurobiology. 2011; 31(7):1009-1020.

146. Chua CW, Lee DT, Ling MT, Zhou C, Man K, Ho J, Chan FL, Wang X and Wong YC. FTY720, a fungus metabolite, inhibits in vivo growth of androgen-independent prostate cancer. Int J Cancer. 2005; 117(6):1039-1048.

147. Permpongkosol S, Wang JD, Takahara S, Matsumiya K, Nonomura N, Nishimura K, Tsujimura A, Kongkanand A and Okuyama A. Anticarcinogenic effect of FTY720 in human prostate carcinoma DU145 cells: modulation of mitogenic signaling, FAK, cell-cycle entry and apoptosis. Int J Cancer. 2002; 98(2):167-172.

148. Wang JD, Takahara S, Nonomura N, Ichimaru N, Toki K, Azuma H, Matsumiya K, Okuyama A and Suzuki S. Early induction of apoptosis in androgen-independent prostate cancer cell line by FTY720 requires caspase-3 activation. Prostate. 1999; 40(1):50-55.

149. Zhou C, Ling MT, Kin-Wah Lee T, Man K, Wang X and Wong YC. FTY720, a fungus metabolite, inhibits invasion ability of androgen-independent prostate cancer cells through inactivation of RhoA-GTPase. Cancer Lett. 2006; 233(1):36-47.

150. Azuma H, Takahara S, Ichimaru N, Wang JD, Itoh Y, Otsuki Y, Morimoto J, Fukui R, Hoshiga M, Ishihara T, Nonomura N, Suzuki S, Okuyama A and Katsuoka Y. Marked prevention of tumor growth and metastasis by a novel immunosuppressive agent, FTY720, in mouse breast cancer models. Cancer Res. 2002; 62(5):1410-1419.

151. Nagaoka Y, Otsuki K, Fujita T and Uesato S. Effects of phosphorylation of immunomodulatory agent FTY720 (fingolimod) on antiproliferative activity against breast and colon cancer cells. Biol Pharm Bull. 2008; 31(6):11771181.

152. Li D, Zhang Y, Hu X, Cao W and Huang W. Role of extracelluar regulated protein kinases in FTY720-induced apoptosis of leukemia cell lines HL-60 and U937. Journal of Huazhong University of Science and Technology Medical sciences. 2004; 24(1):45-47.

153. Liu Q, Zhao X, Frissora F, Ma Y, Santhanam R, Jarjoura D, Lehman A, Perrotti D, Chen CS, Dalton JT, Muthusamy $\mathrm{N}$ and Byrd JC. FTY720 demonstrates promising preclinical activity for chronic lymphocytic leukemia and lymphoblastic leukemia/lymphoma. Blood. 2008; 111(1):275-284.

154. Liu Q, Alinari L, Chen CS, Yan F, Dalton JT, Lapalombella R, Zhang X, Mani R, Lin T, Byrd JC, Baiocchi RA and Muthusamy N. FTY720 shows promising in vitro and in vivo preclinical activity by downmodulating Cyclin D1 and phospho-Akt in mantle cell lymphoma. Clin Cancer Res. 2010; 16(12):3182-3192.

155. Neviani P, Santhanam R, Oaks JJ, Eiring AM, Notari M, Blaser BW, Liu S, Trotta R, Muthusamy N, GambacortiPasserini C, Druker BJ, Cortes J, Marcucci G, Chen CS, Verrills NM, Roy DC, et al. FTY720, a new alternative for treating blast crisis chronic myelogenous leukemia and Philadelphia chromosome-positive acute lymphocytic leukemia. The Journal of clinical investigation. 2007; 117(9):2408-2421.

156. Roberts KG, Smith AM, McDougall F, Carpenter H, Horan M, Neviani P, Powell JA, Thomas D, Guthridge MA, Perrotti D, Sim AT, Ashman LK and Verrills NM. Essential requirement for PP2A inhibition by the oncogenic receptor c-KIT suggests PP2A reactivation as a strategy to treat c-KIT+ cancers. Cancer Res. 2010; 70(13):5438-5447.

157. Yasui H, Hideshima T, Raje N, Roccaro AM, Shiraishi N, Kumar S, Hamasaki M, Ishitsuka K, Tai YT, Podar K, Catley L, Mitsiades CS, Richardson PG, Albert R, Brinkmann V, Chauhan D, et al. FTY720 induces apoptosis in multiple myeloma cells and overcomes drug resistance. Cancer Res. 2005; 65(16):7478-7484.

158. Fujino M, Li XK, Kitazawa Y, Guo L, Kawasaki M, Funeshima N, Amano T and Suzuki S. Distinct pathways of apoptosis triggered by FTY720, etoposide, and anti-Fas antibody in human T-lymphoma cell line (Jurkat cells). The Journal of pharmacology and experimental therapeutics. 2002; 300(3):939-945.

159. Nagahara $Y$, Ikekita $M$ and Shinomiya $T$. Immunosuppressant FTY720 induces apoptosis by direct induction of permeability transition and release of cytochrome c from mitochondria. J Immunol. 2000; 165(6):3250-3259.

160. Lucas da Silva LB, Ribeiro DA, Cury PM, Cordeiro JA and Bueno V. FTY720 treatment in experimentally urethaneinduced lung tumors. J Exp Ther Oncol. 2008; 7(1):9-15.

161. Salinas NR, Lopes CT, Palma PV, Oshima CT and Bueno 
V. Lung tumor development in the presence of sphingosine 1-phosphate agonist FTY720. Pathol Oncol Res. 2009; 15(4):549-554.

162. Salinas NR, Oshima CT, Cury PM, Cordeiro JA and Bueno V. FTY720 and lung tumor development. International immunopharmacology. 2009; 9(6):689-693.

163. Ng KT, Man K, Ho JW, Sun CK, Lee TK, Zhao Y, Lo CM, Poon RT and Fan ST. Marked suppression of tumor growth by FTY720 in a rat liver tumor model: the significance of down-regulation of cell survival Akt pathway. Int J Oncol. 2007; 30(2):375-380.

164. Ho JW, Man K, Sun CK, Lee TK, Poon RT and Fan ST. Effects of a novel immunomodulating agent, FTY720, on tumor growth and angiogenesis in hepatocellular carcinoma. Mol Cancer Ther. 2005; 4(9):1430-1438.

165. Lee TK, Man K, Ho JW, Sun CK, Ng KT, Wang XH, Wong YC, Ng IO, Xu R and Fan ST. FTY720 induces apoptosis of human hepatoma cell lines through PI3-K-mediated Akt dephosphorylation. Carcinogenesis. 2004; 25(12):23972405.

166. Lee TK, Man K, Ho JW, Wang XH, Poon RT, Xu Y, Ng KT, Chu AC, Sun CK, Ng IO, Sun HC, Tang ZY, Xu R and Fan ST. FTY720: a promising agent for treatment of metastatic hepatocellular carcinoma. Clin Cancer Res. 2005; 11(23):8458-8466.

167. Shen Y, Cai M, Xia W, Liu J, Zhang Q, Xie H, Wang C, Wang X and Zheng S. FTY720, a synthetic compound from Isaria sinclairii, inhibits proliferation and induces apoptosis in pancreatic cancer cells. Cancer Lett. 2007; 254(2):288297.

168. Shen Y, Wang X, Xia W, Wang C, Cai M, Xie H, Zhou L and Zheng S. Antiproliferative and overadditive effects of rapamycin and FTY720 in pancreatic cancer cells in vitro. Transplant Proc. 2008; 40(5):1727-1733.

169. Azuma H, Takahara S, Horie S, Muto S, Otsuki Y and Katsuoka Y. Induction of apoptosis in human bladder cancer cells in vitro and in vivo caused by FTY720 treatment. J Urol. 2003; 169(6):2372-2377.

170. Ubai T, Azuma H, Kotake Y, Inamoto T, Takahara K, Ito Y, Kiyama S, Sakamoto T, Horie S, Muto S, Takahara S, Otsuki Y and Katsuoka Y. FTY720 induced Bcl-associated and Fas-independent apoptosis in human renal cancer cells in vitro and significantly reduced in vivo tumor growth in mouse xenograft. Anticancer Res. 2007; 27(1A):75-88.

171. Lee WJ, Yoo HS, Suh PG, Oh S, Lim JS and Lee YM. Sphingosine mediates FTY720-induced apoptosis in LLCPK1 cells. Experimental \& molecular medicine. 2004; 36(5):420-427.

172. Sonoda Y, Yamamoto D, Sakurai S, Hasegawa M, AizuYokota E, Momoi T and Kasahara T. FTY720, a novel immunosuppressive agent, induces apoptosis in human glioma cells. Biochemical and biophysical research communications. 2001; 281(2):282-288.

173. Zheng T, Meng X, Wang J, Chen X, Yin D, Liang Y, Song
X, Pan S, Jiang H and Liu L. PTEN- and p53-mediated apoptosis and cell cycle arrest by FTY720 in gastric cancer cells and nude mice. Journal of cellular biochemistry. 2010; 111(1):218-228.

174. Xing Y, Wang ZH, Ma DH and Han Y. FTY720 enhances chemosensitivity of colon cancer cells to doxorubicin and etoposide via the modulation of P-glycoprotein and multidrug resistance protein 1 . Journal of digestive diseases. 2014; 15(5):246-259.

175. Zhang N, Qi Y, Wadham C, Wang L, Warren A, Di W and Xia P. FTY720 induces necrotic cell death and autophagy in ovarian cancer cells: a protective role of autophagy. Autophagy. 2010; 6(8):1157-1167.

176. Cristobal I, Manso R, Rincon R, Carames C, Senin C, Borrero A, Martinez-Useros J, Rodriguez M, Zazo S, Aguilera O, Madoz-Gurpide J, Rojo F and Garcia-Foncillas J. PP2A inhibition is a common event in colorectal cancer and its restoration using FTY720 shows promising therapeutic potential. Molecular cancer therapeutics. 2014; 13(4):938-947.

177. Rosa R, Marciano R, Malapelle U, Formisano L, Nappi L, D'Amato C, D'Amato V, Damiano V, Marfe G, Del Vecchio S, Zannetti A, Greco A, De Stefano A, Carlomagno C, Veneziani BM, Troncone G, et al. Sphingosine kinase 1 overexpression contributes to cetuximab resistance in human colorectal cancer models. Clinical cancer research. 2013; 19(1):138-147.

178. Marcus A and Eshhar Z. Allogeneic chimeric antigen receptor-modified cells for adoptive cell therapy of cancer. Expert opinion on biological therapy. 2014; 14(7):947-954.

179. LaMontagne K, Littlewood-Evans A, Schnell C, O'Reilly T, Wyder L, Sanchez T, Probst B, Butler J, Wood A, Liau G, Billy E, Theuer A, Hla T and Wood J. Antagonism of sphingosine-1-phosphate receptors by FTY720 inhibits angiogenesis and tumor vascularization. Cancer Res. 2006; 66(1):221-231.

180. Zhang L, Wang H, Zhu J, Ding K and Xu J. FTY720 reduces migration and invasion of human glioblastoma cell lines via inhibiting the PI3K/AKT/mTOR/p70S6K signaling pathway. Tumour biology. 2014; 35:10707-14.

181. Wolf AM, Eller K, Zeiser R, Durr C, Gerlach UV, Sixt M, Markut L, Gastl G, Rosenkranz AR and Wolf D. The sphingosine 1-phosphate receptor agonist FTY720 potently inhibits regulatory $\mathrm{T}$ cell proliferation in vitro and in vivo. $\mathrm{J}$ Immunol. 2009; 183(6):3751-3760.

182. Nishikawa H and Sakaguchi S. Regulatory T cells in tumor immunity. Int J Cancer. 2010; 127(4):759-767.

183. Domhan S, Zeier M and Abdollahi A. Immunosuppressive therapy and post-transplant malignancy. Nephrol Dial Transplant. 2009; 24(4):1097-1103.

184. Liang J, Nagahashi M, Kim EY, Harikumar KB, Yamada A, Huang WC, Hait NC, Allegood JC, Price MM, Avni D, Takabe K, Kordula T, Milstien S and Spiegel S. Sphingosine-1-phosphate links persistent STAT3 activation, 
chronic intestinal inflammation, and development of colitisassociated cancer. Cancer cell. 2013; 23(1):107-120.

185. Nagahashi M, Hait NC, Maceyka M, Avni D, Takabe K, Milstien S and Spiegel S. Sphingosine-1-phosphate in chronic intestinal inflammation and cancer. Advances in biological regulation. 2014; 54:112-120.

186. Loveridge C, Tonelli F, Leclercq T, Lim KG, Long JS, Berdyshev E, Tate RJ, Natarajan V, Pitson SM, Pyne NJ and Pyne S. The sphingosine kinase 1 inhibitor 2-(p-hydroxyanilino)-4-(p-chlorophenyl)thiazole induces proteasomal degradation of sphingosine kinase 1 in mammalian cells. J Biol Chem. 2010; 285(50):3884138852.

187. Ren S, Xin C, Pfeilschifter J and Huwiler A. A novel mode of action of the putative sphingosine kinase inhibitor 2-(p-hydroxyanilino)-4-(p-chlorophenyl) thiazole (SKI II): induction of lysosomal sphingosine kinase 1 degradation. Cell Physiol Biochem. 2010; 26(1):97-104.

188. Ishitsuka A, Fujine E, Mizutani Y, Tawada C, Kanoh H, Banno Y and Seishima M. FTY720 and cisplatin synergistically induce the death of cisplatin-resistant melanoma cells through the downregulation of the PI3K pathway and the decrease in epidermal growth factor receptor expression. Int J Mol Med. 2014; 34(4):1169-1174.

189. Perrotti D and Neviani P. Protein phosphatase 2A (PP2A), a drugable tumor suppressor in $\mathrm{Ph} 1(+)$ leukemias. Cancer metastasis reviews. 2008; 27(2):159-168.

190. Neviani P, Santhanam R, Trotta R, Notari M, Blaser BW, Liu S, Mao H, Chang JS, Galietta A, Uttam A, Roy DC, Valtieri M, Bruner-Klisovic R, Caligiuri MA, Bloomfield $\mathrm{CD}$, Marcucci $\mathrm{G}$, et al. The tumor suppressor PP2A is functionally inactivated in blast crisis CML through the inhibitory activity of the BCR/ABL-regulated SET protein. Cancer cell. 2005; 8(5):355-368.

191. Westermarck J and Hahn WC. Multiple pathways regulated by the tumor suppressor PP2A in transformation. Trends in molecular medicine. 2008; 14(4):152-160.

192. Cristobal I, Garcia-Orti L, Cirauqui C, Alonso MM, Calasanz MJ and Odero MD. PP2A impaired activity is a common event in acute myeloid leukemia and its activation by forskolin has a potent anti-leukemic effect. Leukemia. 2011; 25(4):606-614.

193. Baldacchino S, Saliba C, Petroni V, Fenech AG, Borg N and Grech G. Deregulation of the phosphatase, PP2A is a common event in breast cancer, predicting sensitivity to FTY720. The EPMA journal. 2014; 5(1):3.

194. Perrotti D and Neviani P. Protein phosphatase 2A: a target for anticancer therapy. Lancet Oncol. 2013; 14(6):e229238.

195. Kalla C, Scheuermann MO, Kube I, Schlotter M, Mertens D, Dohner H, Stilgenbauer S and Lichter P. Analysis of 11q22-q23 deletion target genes in B-cell chronic lymphocytic leukaemia: evidence for a pathogenic role of NPAT, CUL5, and PPP2R1B. Eur J Cancer. 2007;
43(8):1328-1335.

196. Matsuoka Y, Nagahara Y, Ikekita M and Shinomiya T. A novel immunosuppressive agent FTY720 induced Akt dephosphorylation in leukemia cells. British journal of pharmacology. 2003; 138(7):1303-1312.

197. Dobrowsky RT, Kamibayashi C, Mumby MC and Hannun YA. Ceramide activates heterotrimeric protein phosphatase 2A. The Journal of biological chemistry. 1993; 268(21):15523-15530.

198. Suzuki E, Handa K, Toledo MS and Hakomori S. Sphingosine-dependent apoptosis: a unified concept based on multiple mechanisms operating in concert. Proceedings of the National Academy of Sciences of the United States of America. 2004; 101(41):14788-14793.

199. Ruvolo PP, Clark W, Mumby M, Gao F and May WS. A functional role for the B56 alpha-subunit of protein phosphatase 2A in ceramide-mediated regulation of $\mathrm{Bcl} 2$ phosphorylation status and function. The Journal of biological chemistry. 2002; 277(25):22847-22852.

200. Ruvolo PP, Deng X, Ito T, Carr BK and May WS. Ceramide induces Bcl2 dephosphorylation via a mechanism involving mitochondrial PP2A. The Journal of biological chemistry. 1999; 274(29):20296-20300.

201. Mukhopadhyay A, Saddoughi SA, Song P, Sultan I, Ponnusamy S, Senkal CE, Snook CF, Arnold HK, Sears RC, Hannun YA and Ogretmen B. Direct interaction between the inhibitor 2 and ceramide via sphingolipidprotein binding is involved in the regulation of protein phosphatase 2A activity and signaling. FASEB J. 2009; 23(3):751-763.

202. Habrukowich C, Han DK, Le A, Rezaul K, Pan W, Ghosh M, Li Z, Dodge-Kafka K, Jiang X, Bittman R and Hla T. Sphingosine interaction with acidic leucine-rich nuclear phosphoprotein-32A (ANP32A) regulates PP2A activity and cyclooxygenase (COX)-2 expression in human endothelial cells. The Journal of biological chemistry. 2010; 285(35):26825-26831.

203. Liu H, Gu Y, Yin J, Zheng G, Wang C, Zhang Z, Deng M, Liu J, Jia X and He Z. SET-mediated NDRG1 inhibition is involved in acquisition of epithelial-to-mesenchymal transition phenotype and cisplatin resistance in human lung cancer cell. Cellular signalling. 2014; 26(12):2710-2720.

204. Ruvolo PP, Ruvolo VR, Jacamo R, Burks JK, Zeng Z, Duvvuri SR, Zhou L, Qiu Y, Coombes KR, Zhang N, Yoo SY, Pan R, Hail N, Jr., Konopleva M, Calin G, Kornblau $\mathrm{SM}$, et al. The protein phosphatase $2 \mathrm{~A}$ regulatory subunit B55alpha is a modulator of signaling and microRNA expression in acute myeloid leukemia cells. Biochimica et biophysica acta. 2014; 1843(9):1969-1977.

205. Neviani P, Harb JG, Oaks JJ, Santhanam R, Walker CJ, Ellis JJ, Ferenchak G, Dorrance AM, Paisie CA, Eiring AM, Ma Y, Mao HC, Zhang B, Wunderlich M, May PC, Sun $\mathrm{C}$, et al. PP2A-activating drugs selectively eradicate TKI-resistant chronic myeloid leukemic stem cells. The Journal of clinical investigation. 2013; 123(10):4144-4157. 
206. Mani R, Mao Y, Frissora FW, Chiang CL, Wang J, Zhao Y, Wu Y, Yu B, Yan R, Mo X, Yu L, Flynn J, Jones J, Andritsos L, Baskar S, Rader C, et al. Tumor antigen ROR1 targeted drug delivery mediated selective leukemic but not normal B cell cytotoxicity in chronic lymphocytic leukemia. Leukemia. 2014.

207. Oaks JJ, Santhanam R, Walker CJ, Roof S, Harb JG, Ferenchak G, Eisfeld AK, Van Brocklyn JR, Briesewitz R, Saddoughi SA, Nagata K, Bittman R, Caligiuri MA, AbdelWahab O, Levine R, Arlinghaus RB, et al. Antagonistic activities of the immunomodulator and PP2A-activating drug FTY720 (Fingolimod, Gilenya) in Jak2-driven hematologic malignancies. Blood. 2013; 122(11):19231934.

208. Saddoughi SA, Gencer S, Peterson YK, Ward KE, Mukhopadhyay A, Oaks J, Bielawski J, Szulc ZM, Thomas RJ, Selvam SP, Senkal CE, Garrett-Mayer E, De Palma RM, Fedarovich D, Liu A, Habib AA, et al. Sphingosine analogue drug FTY720 targets I2PP2A/SET and mediates lung tumour suppression via activation of PP2A-RIPK1dependent necroptosis. EMBO molecular medicine. 2013; 5(1):105-121.

209. Brinkmann V, Davis MD, Heise CE, Albert R, Cottens S, Hof R, Bruns C, Prieschl E, Baumruker T, Hiestand $\mathrm{P}$, Foster CA, Zollinger M and Lynch KR. The immune modulator FTY720 targets sphingosine 1-phosphate receptors. The Journal of biological chemistry. 2002; 277(24):21453-21457.

210. Ushitora Y, Tashiro H, Ogawa T, Tanimoto Y, Kuroda S, Kobayashi T, Miyata Y, Itamoto T, Asahara T and Ohdan H. Suppression of hepatocellular carcinoma recurrence after rat liver transplantation by FTY720, a sphingosine-1phosphate analog. Transplantation. 2009; 88(8):980-986.

211. Kluk MJ, Ryan KP, Wang B, Zhang G, Rodig SJ and Sanchez T. Sphingosine-1-phosphate receptor 1 in classical Hodgkin lymphoma: assessment of expression and role in cell migration. Laboratory investigation. 2013; 93(4):462471.

212. Nam SW, Clair T, Campo CK, Lee HY, Liotta LA and Stracke ML. Autotaxin (ATX), a potent tumor motogen, augments invasive and metastatic potential of rastransformed cells. Oncogene. 2000; 19(2):241-247.

213. Nam SW, Clair T, Kim YS, McMarlin A, Schiffmann E, Liotta LA and Stracke ML. Autotaxin (NPP-2), a metastasis-enhancing motogen, is an angiogenic factor. Cancer research. 2001; 61(18):6938-6944.

214. Lee HY, Bae GU, Jung ID, Lee JS, Kim YK, Noh SH, Stracke ML, Park CG, Lee HW and Han JW. Autotaxin promotes motility via $\mathrm{G}$ protein-coupled phosphoinositide 3-kinase gamma in human melanoma cells. FEBS letters. 2002; 515(1-3):137-140.

215. Umezu-Goto M, Kishi Y, Taira A, Hama K, Dohmae N, Takio K, Yamori T, Mills GB, Inoue K, Aoki J and Arai H. Autotaxin has lysophospholipase D activity leading to tumor cell growth and motility by lysophosphatidic acid production. The Journal of cell biology. 2002; 158(2):227233.

216. Yang SY, Lee J, Park CG, Kim S, Hong S, Chung HC, Min SK, Han JW, Lee HW and Lee HY. Expression of autotaxin (NPP-2) is closely linked to invasiveness of breast cancer cells. Clinical \& experimental metastasis. 2002; 19(7):603608.

217. Gijsbers R, Aoki J, Arai H and Bollen M. The hydrolysis of lysophospholipids and nucleotides by autotaxin (NPP2) involves a single catalytic site. FEBS letters. 2003; 538(13):60-64.

218. Koh E, Clair T, Woodhouse EC, Schiffmann E, Liotta L and Stracke M. Site-directed mutations in the tumor-associated cytokine, autotaxin, eliminate nucleotide phosphodiesterase, lysophospholipase D, and motogenic activities. Cancer research. 2003; 63(9):2042-2045.

219. van Meeteren LA, Brinkmann V, Saulnier-Blache JS, Lynch KR and Moolenaar WH. Anticancer activity of FTY720: phosphorylated FTY720 inhibits autotaxin, a metastasisenhancing and angiogenic lysophospholipase D. Cancer letters. 2008; 266(2):203-208.

220. Matsumura M, Tsuchida M, Isoyama N, Takai K and Matsuyama H. FTY720 mediates cytochrome c release from mitochondria during rat thymocyte apoptosis. Transplant immunology. 2010; 23(4):174-179.

221. Kiyota M, Kuroda J, Yamamoto-Sugitani M, Shimura Y, Nakayama R, Nagoshi H, Mizutani S, Chinen Y, Sasaki N, Sakamoto N, Kobayashi T, Matsumoto Y, Horiike S and Taniwaki M. FTY720 induces apoptosis of chronic myelogenous leukemia cells via dual activation of BIM and BID and overcomes various types of resistance to tyrosine kinase inhibitors. Apoptosis. 2013; 18(11):1437-1446.

222. Nagahara Y, Ikekita M and Shinomiya T. T cell selective apoptosis by a novel immunosuppressant, FTY720, is closely regulated with Bcl-2. British journal of pharmacology. 2002; 137(7):953-962.

223. Azuma H, Horie S, Muto S, Otsuki Y, Matsumoto K, Morimoto J, Gotoh R, Okuyama A, Suzuki S, Katsuoka $\mathrm{Y}$ and Takahara S. Selective cancer cell apoptosis induced by FTY720; evidence for a Bcl-dependent pathway and impairment in ERK activity. Anticancer Res. 2003; 23(4):3183-3193.

224. Marvaso G, Barone A, Amodio N, Raimondi L, Agosti V, Altomare E, Scotti V, Lombardi A, Bianco R, Bianco C, Caraglia M, Tassone P and Tagliaferri P. Sphingosine analog fingolimod (FTY720) increases radiation sensitivity of human breast cancer cells in vitro. Cancer Biol Ther. 2014; 15(6):797-805.

225. Li MH, Hla T and Ferrer F. FTY720 inhibits tumor growth and enhances the tumor-suppressive effect of topotecan in neuroblastoma by interfering with the sphingolipid signaling pathway. Pediatric blood \& cancer. 2013; 60(9):1418-1423.

226. Woodcock JM, Ma Y, Coolen C, Pham D, Jones C, Lopez 
AF and Pitson SM. Sphingosine and FTY720 directly bind pro-survival 14-3-3 proteins to regulate their function. Cellular signalling. 2010; 22(9):1291-1299.

227. Ma Y, Pitson S, Hercus T, Murphy J, Lopez A and Woodcock J. Sphingosine activates protein kinase A type II by a novel cAMP-independent mechanism. The Journal of biological chemistry. 2005; 280(28):26011-26017.

228. Hamaguchi A, Suzuki E, Murayama K, Fujimura T, Hikita T, Iwabuchi K, Handa K, Withers DA, Masters SC, Fu H and Hakomori S. Sphingosine-dependent protein kinase-1, directed to $14-3-3$, is identified as the kinase domain of protein kinase $\mathrm{C}$ delta. The Journal of biological chemistry. 2003; 278(42):41557-41565.

229. Cristobal I, Gonzalez-Alonso P, Daoud L, Solano E, Torrejon B, Manso R, Madoz-Gurpide J, Rojo F and Garcia-Foncillas J. Activation of the Tumor Suppressor PP2A Emerges as a Potential Therapeutic Strategy for Treating Prostate Cancer. Mar Drugs. 2015; 13(6):32763286.

230. Zhang X, Goncalves R and Mosser DM. The isolation and characterization of murine macrophages. Curr Protoc Immunol. 2008; Chapter 14:Unit 1411.

231. Fransson R, McCracken AN, Chen B, McMonigle RJ, Edinger AL and Hanessian S. Design, Synthesis, and Antileukemic Activity of Stereochemically Defined Constrained Analogs of FTY720 (Gilenya). ACS medicinal chemistry letters. 2013; 4(10).

232. Li YC, Liu ZG, Yao K, Wang HH, Hu R, Yang W and Liao AJ. [Mechanisms of ROS in U266 cell death induced by FTY720]. Chinese Association of Pathophysiology. 2013; 21(3):643-646.

233. Zhang N, Dai L, Qi Y, Di W and Xia P. Combination of FTY720 with cisplatin exhibits antagonistic effects in ovarian cancer cells: role of autophagy. International journal of oncology. 2013; 42(6):2053-2059.

234. Pereira FV, Arruda DC, Figueiredo CR, Massaoka MH, Matsuo AL, Bueno V and Rodrigues EG. FTY720 induces apoptosis in B16F10-NEX2 murine melanoma cells, limits metastatic development in vivo, and modulates the immune system. Clinics. 2013; 68(7):1018-1027.

235. Lu Z, Wang J, Zheng T, Liang Y, Yin D, Song R, Pei T, Pan S, Jiang H and Liu L. FTY720 inhibits proliferation and epithelial-mesenchymal transition in cholangiocarcinoma by inactivating STAT3 signaling. BMC Cancer. 2014; 14:783.

236. Zhang L, Wang H, Zhu J, Ding K and Xu J. FTY720 reduces migration and invasion of human glioblastoma cell lines via inhibiting the PI3K/AKT/mTOR/p70S6K signaling pathway. Tumour Biol. 2014; 35(11):1070710714.

237. Marvaso G, Barone A, Amodio N, Raimondi L, Agosti V, Altomare E, Scotti V, Lombardi A, Bianco R, Bianco C, Caraglia M, Tassone P and Tagliaferri P. Sphingosine analog fingolimod (FTY720) increases radiation sensitivity of human breast cancer cells in vitro. Cancer biology \& therapy. 2014; 15(6):797-805.

238. Cohen JA, Barkhof F, Comi G, Hartung HP, Khatri BO, Montalban X, Pelletier J, Capra R, Gallo P, Izquierdo G, Tiel-Wilck K, de Vera A, Jin J, Stites T, Wu S, Aradhye $\mathrm{S}$, et al. Oral fingolimod or intramuscular interferon for relapsing multiple sclerosis. N Engl J Med. 2010; 362(5):402-415.

239. Kappos L, Radue EW, O'Connor P, Polman C, Hohlfeld R, Calabresi P, Selmaj K, Agoropoulou C, Leyk M, ZhangAuberson L and Burtin P. A placebo-controlled trial of oral fingolimod in relapsing multiple sclerosis. N Engl J Med. 2010; 362(5):387-401.

240. Onishi H, Kiyota A, Koya N, Tanaka H, Umebayashi M, Katano $\mathrm{M}$ and Morisaki T. Random migration contributes to cytotoxicity of activated CD8+ T-lymphocytes but not NK cells. Anticancer research. 2014; 34(8):3947-3956.

241. Omar HA, Chou CC, Berman-Booty LD, Ma Y, Hung JH, Wang D, Kogure T, Patel T, Terracciano L, Muthusamy N, Byrd JC, Kulp SK and Chen CS. Antitumor effects of OSU-2S, a nonimmunosuppressive analogue of FTY720, in hepatocellular carcinoma. Hepatology. 2011; 53(6):19431958.

242. Mao Y, Wang J, Zhao Y, Yan R, Li H, Chen CS, Lee RJ, Byrd JC, Lee LJ, Muthusamy N and Phelps MA. Quantification of OSU-2S, a novel derivative of FTY720, in mouse plasma by liquid chromatography-tandem mass spectrometry. Journal of pharmaceutical and biomedical analysis. 2014; 98:160-165.

243. Mao Y, Wang J, Zhao Y, Wu Y, Kwak KJ, Chen CS, Byrd JC, Lee RJ, Phelps MA, Lee LJ and Muthusamy N. A novel liposomal formulation of FTY720 (fingolimod) for promising enhanced targeted delivery. Nanomedicine. 2014; 10(2):393-400.

244. Yu B, Mao Y, Yuan Y, Yue C, Wang X, Mo X, Jarjoura D, Paulaitis ME, Lee RJ, Byrd JC, Lee LJ and Muthusamy N. Targeted drug delivery and cross-linking induced apoptosis with anti-CD37 based dual-ligand immunoliposomes in B chronic lymphocytic leukemia cells. Biomaterials. 2013; 34(26):6185-6193.

245. Spranger S, Koblish HK, Horton B, Scherle PA, Newton $\mathrm{R}$ and Gajewski TF. Mechanism of tumor rejection with doublets of CTLA-4, PD-1/PD-L1, or IDO blockade involves restored IL-2 production and proliferation of CD8(+) T cells directly within the tumor microenvironment. Journal for immunotherapy of cancer. 2014; 2:3.

246. Kappos L, Antel J, Comi G, Montalban X, O’Connor P, Polman CH, Haas T, Korn AA, Karlsson G and Radue EW. Oral fingolimod (FTY720) for relapsing multiple sclerosis. N Engl J Med. 2006; 355(11):1124-1140.

247. Buddaseth S, Gottmann W, Blasczyk R and Huyton T. Overexpression of the pp32r1 (ANP32C) oncogene or its functional mutant pp32r1Y140H confers enhanced resistance to FTY720 (Finguimod). Cancer Biol Ther. 2014; 15(3):289-296. 
248. Pchejetski D, Bohler T, Stebbing J and Waxman J. Therapeutic potential of targeting sphingosine kinase 1 in prostate cancer. Nat Rev Urol. 2011; 8(10):569-678.

249. Alshaker H, Sauer L, Monteil D, Ottaviani S, Srivats $\mathrm{S}$, Bohler T and Pchejetski D. Therapeutic potential of targeting SK1 in human cancers. Adv Cancer Res. 2013; 117:143-200.
250. Pitson SM. Regulation of sphingosine kinase and sphingolipid signaling. Trends Biochem Sci. 2011; 36(2):97-107. 